\title{
Stock Market Development under Globalization: Whither the Gains from Reforms?
}

\author{
Augusto de la Torre \\ Juan Carlos Gozzi \\ and \\ Sergio L. Schmukler*
}

\begin{abstract}
Over the last decades, many countries have implemented significant reforms to foster domestic capital market development. These reforms included stock market liberalization, privatization programs, and the establishment of regulatory and supervisory frameworks. Despite the intense reform efforts, the performance of capital markets in several countries has been disappointing. To study whether reforms have had the intended effects on capital markets, we analyze the impact of six capital market reforms on domestic stock market development and internationalization, using event studies. We find that reforms tend to be followed by significant increases in domestic market capitalization, trading, and capital raising. Reforms are also followed by an increase in the share of activity in international equity markets, with potential negative spillover effects on domestic markets.
\end{abstract}

JEL classification codes: G15, G18, G20

Keywords: capital market development; capital market reforms; internationalization of financial markets; cross-listing; ADRs

World Bank Policy Research Working Paper 4184, April 2007

The Policy Research Working Paper Series disseminates the findings of work in progress to encourage the exchange of ideas about development issues. An objective of the series is to get the findings out quickly, even if the presentations are less than fully polished. The papers carry the names of the authors and should be cited accordingly. The findings, interpretations, and conclusions expressed in this paper are entirely those of the authors. They do not necessarily represent the view of the World Bank, its Executive Directors, or the countries they represent. Policy Research Working Papers are available online at http://econ.worldbank.org.

* Authors are with the World Bank. Gozzi is also with Brown University. The paper was written while Schmukler was visiting the IMF Research Department. For helpful comments, we are grateful to Eduardo Fernandez Arias, Fari Moshirian, Luis Servén, and participants at the Journal of Banking and FinanceWorld Bank conference "Globalization and Financial Services in Emerging Economies." We are grateful to José Azar and Marina Halac for excellent research assistance. This paper is part of a broader study on capital markets, conducted at the Chief Economist Office, Latin America and the Caribbean Region, World Bank, available at: http://www.worldbank.org/laccapitalmarkets. Email addresses: adelatorre@worldbank.org, juan_carlos_gozzi_valdez@brown.edu, and sschmukler@worldbank.org. 


\section{Introduction}

Over the last two decades, a large number of countries, both developed and developing, have implemented significant capital market reforms, including stock market liberalization, improvements in securities clearance and settlements systems, and the development of regulatory and supervisory frameworks. These reforms, together with improved macroeconomic fundamentals and related reforms, such as the privatization of state-owned enterprises and the shift to privately managed defined contribution pension systems, were expected to foster domestic financial development. ${ }^{1}$ These expectations were supported by the growing cross-sectional empirical evidence on the determinants of stock market development, which shows that countries with sounder macroeconomic policies, better institutional environments, and more efficient legal systems, especially regarding the protection of minority investors, have more developed domestic markets. ${ }^{2}$

Capital market reforms were also expected to foster domestic market development through their impact on the stock market internationalization process. According to this argument, poor domestic environments prompt firms and investors to use international markets more intensively. A poor domestic environment has long been considered one of the main reasons for capital flight and greater use by domestic residents of financial services offered abroad (see, for example, Collier, Hoeffler, and Pattillo, 2000). Over the last decades, there has been an increasing migration of securities market activities to major international financial centers, such as New York and London. As part of this globalization process, Depositary Receipts (DRs) have become increasingly popular instruments. ${ }^{3}$ For many developing countries, activity in international markets now exceeds domestic stock market activity. A number of papers argue that this internationalization process is the result of firms trying to escape from poor domestic

\footnotetext{
${ }^{1}$ This has been deemed an important goal, as financial development is linked to economic growth. For more than a century, economists have emphasized the importance of financial development for growth. Historically, the literature focused on the role of banks, beginning with Bagehot (1873) and Schumpeter (1912). More recently, Atje and Jovanovic (1993), King and Levine (1993), and Levine and Zervos (1998a), among many others, have documented that financial development leads to growth. See Levine (1997) for a review of the earlier literature and Levine (2005) for an update.

${ }^{2}$ The literature on domestic stock market development has found that more developed countries tend to have deeper stock markets (see, for example, Rajan and Zingales, 2003 and La Porta, Lopez-de-Silanes, and Shleifer, 2006) and that the laws and enforcement mechanisms that protect the rights of minority investors foster equity market development (La Porta et al., 1997, 1998). Macroeconomic stability has also been found to promote financial development (IADB, 1995; Boyd, Levine, and Smith, 2001).

${ }^{3}$ There are different alternatives to cross-list domestic stocks in international financial markets. A very popular way to do so is through depositary receipts, called American Depositary Receipts (ADRs) or Global Depositary Receipts (GDRs). These are foreign currency denominated derivative instruments, issued by international banks like Bank of New York or Citibank, representing home securities held with a local custodian. Trading in DRs in U.S. exchanges has expanded from 75 billion U.S. dollars in 1990 to one trillion in 2005, and there are currently more than 1,900 sponsored ADR programs, issued by firms from 73 countries.
} 
environments with weak institutions and poorly functioning markets. ${ }^{4}$ This view implies that capital market reforms will reduce incentives for firms to internationalize and will result in a lower share of equity market activities taking place abroad. This may have significant implications for domestic market development, as the migration of trading to international financial centers can have negative spillover effects on local markets. ${ }^{5}$

Despite the intense reform efforts, the performance of local capital markets in many developing countries has been disappointing. Although some countries experienced growth of their stock markets, this growth was not as significant as the one witnessed by the most advanced nations. Other countries experienced an actual deterioration of their domestic capital markets. ${ }^{6}$ Stock markets in many developing countries remain highly illiquid and segmented, with trading and capitalization concentrated on few stocks. The large number of policy initiatives and reforms and the dismal performance of capital markets have raised several questions. Is it possible that capital markets do not respond to reforms and that the policy prescriptions were based just on cross-country evidence? Is more time needed to see the full fruits of reforms? Does the reform agenda need to be rethought? ${ }^{7}$

In this paper we try to shed light on this issue, by analyzing how capital marketspecific and related reforms have impacted both the development of domestic stock markets and the internationalization of stock market activities (listing, trading, and capital raising). We focus our analysis on six reforms that can potentially contribute to the development of stock markets, for which we were able to collect data on implementation dates for a large number of countries. These reforms are: stock market liberalization, enforcement of insider trading laws, introduction of fully automated electronic trading systems, privatization programs, structural pension reform (i.e., shifting from a public

\footnotetext{
${ }^{4}$ Karolyi (2004), for example, argues that the growth of ADR programs in emerging economies is the result of poorly functioning stock markets, resulting from economic, political, legal, or other institutional forces that generate incentives for firms to leave. This view is also behind the recent literature on "bonding," which argues that cross-listing in an exchange with better investor protection is a form of bonding, creating a credible and binding commitment by the issuer to protect the interests of minority shareholders. See Benos and Weisbach (2004) for a review of this literature.

${ }^{5}$ Levine and Schmukler (2006a,b) analyze the impact of migration to international markets on domestic stock market trading and liquidity. Moel (2001) and Karolyi (2004) also present evidence on how the use of ADRs is related to stock market development in emerging economies

${ }^{6}$ See de la Torre and Schmukler (2006) for a description of the evolution of capital markets over the last decades, with a focus on Latin America.

${ }^{7}$ From a more general perspective, Easterly (2001) finds that, despite significant policy reforms, developing countries have on average stagnated over the last two decades. He argues that worldwide factors may have contributed to this stagnation and says that this evidence deals a significant blow to the optimism surrounding the "Washington Consensus." Others have questioned the benefits of specific capital marketrelated reforms, such as capital account liberalization (see, for example, Rodrik, 1998 and Stiglitz, 2000).
} 
defined benefit pay-as-you-go system to a privately managed funded defined contribution system), and institutional reform. ${ }^{8}$

From an academic perspective, the value added of this paper is to analyze the impact of different capital market reforms using the same framework and extend the analysis beyond domestic stock markets, including activity in international equity markets. There are a number of papers that analyze the impact of some of these reforms on certain aspects of local stock markets and on macroeconomic variables, such as growth and investment. We discuss these papers below, when describing in detail each reform covered by our study. However, these papers tend focus only on one reform and usually analyze its impact on a specific aspect of domestic stock markets, such as returns or size. We instead study the impact of six reforms on domestic markets, using three indicators of stock market development: capitalization, trading activity, and capital raising. Furthermore, none of these papers include international activity in their analyses. This represents an important limitation, given the significant participation of many countries in international equity markets.

From an academic and policy perspective, our study allows policymakers to go beyond cross-country evidence and understand the within-country impact of reforms. Although the cross-country analysis of the determinants of stock market development is very informative, it presents some shortcomings from the standpoint of each country. The relevant policy question is how capital market reforms and improvements in the enabling environment will affect a country's stock market. Cross-country evidence might not be very helpful in this respect, as some variables are completely exogenous and beyond the control of policymakers. ${ }^{9}$ And even when the government can manipulate some variables, it may be very difficult and might take a very long time for a developing country to replicate the environment existent in rich countries, which is the one thought to be optimal for finance to flourish. Even panel data analysis may be of limited assistance, as there may be little time variation in the macroeconomic and institutional environment and panel results might thus be driven by cross-country differences. In this paper, we shift the attention away from estimating the cross-sectional relation between fundamentals and stock market development, and focus instead on event studies, which show the withincountry changes in stock market development and internationalization around capital market reforms. ${ }^{10} \mathrm{We}$ view this approach as complementary to the panel and cross-country analysis documented so far in the literature.

\footnotetext{
${ }^{8}$ Some of these reforms were specifically directed to improving the functioning of domestic stock markets. Others, such as privatization, pension reform, and institutional reform, were implemented due to other reasons, including reducing public expenditures and improving the business environment, but were part of an overall strategy to foster market activity and were expected to support capital market development.

${ }^{9}$ The inclusion of clearly exogenous variables, such as legal origin, religion, or geographical endowments, while informative from an analytical perspective, provides no guidance to policymakers about which course of action to take.

${ }^{10}$ Wacziarg and Welch (2003) highlight the limitations of cross-country analyses in their study of trade liberalization. They find that cross-sectional evidence shows no significant impact of trade openness on
} 
We find that reforms are associated with increases in domestic stock market capitalization, trading, and capital raising, contrary to the claim that they are not effective. However, we also find that reforms are associated with increased internationalization, and that some of the reforms seem to have been followed by a higher share of activity in international markets. This runs contrary to the view that a poor domestic environment prompts firms to access international markets and that reforms reduce internationalization.

Most of the results are robust to controlling for domestic and international macroeconomic variables. These controls are important because capital market reforms can be contemporaneous to other policy changes (such as macroeconomic stabilization programs, trade liberalization, and the easing of exchange rate controls) or may occur at high points in the domestic and/or international business cycle. Since many countries implemented several capital market reforms in a short period of time, when analyzing each reform we also control for other reforms clustered around that time. We find that our results remain mostly unchanged when including this control, suggesting that the reforms under analysis tend to have a positive marginal effect on domestic stock market development and internationalization. We also present some robustness tests controlling for time effects in the regressions of domestic stock market development variables and find that some of the reform dummies remain statistically significant and positive.

The rest of the paper is structured as follows. Section 2 describes the data and the reforms under analysis. Section 3 presents the empirical results on the impact of reforms on domestic stock market development and internationalization. Section 4 discusses some potential interpretation problems and presents robustness tests. Section 5 summarizes the main results and concludes.

\section{Data}

This section presents the data used in the paper. We first describe the data on stock market activity, both in domestic markets and abroad, and then discuss in detail the reforms we analyze.

\subsection{Stock market activity data}

As measures of stock market activity, we use three variables: market capitalization, value traded, and amount of equity capital raised. For all, we need data for both domestic and international activity. While there are several sources on domestic stock market capitalization and value traded that comprise a large number of countries, there is no comprehensive database on capital raised domestically. There are even less data available

growth during the 1990s. In contrast to these cross-sectional findings, their within-country evidence shows that trade liberalization has a robust positive impact on growth and investment rates. 
on the extent of the internationalization of stock market activities. Therefore, we need to combine a number of sources. ${ }^{11}$

On domestic activity, the data on market capitalization and value traded on the major local stock exchanges come from the Standard \& Poor's Emerging Markets Database and Global Stock Markets Factbook and cover the period 1975-2004 for 117 countries. The amount of equity capital raised by domestic firms in the local stock market comes from the World Federation of Exchanges and covers the period 1982-2004 for 46 countries.

On international activity, we use data from Claessens, Klingebiel, and Schmukler (2006), who collect firm-level information from several sources and aggregate it to obtain country-level variables. Here, we only present a brief description of these data. In terms of trading in international markets, the data come from the Bank of New York and cover trading in ADRs for the period 1989-2000. Capital raised abroad refers to the sum of the amount of new equity financing which is obtained by using a non-domestic instrument (such as a foreign listing or an ADR) and any new equity issue abroad. The data come from two different sources. One is the Bank of New York and covers capital raised through ADRs from 1980 to 2000. The other dataset is compiled by Euromoney and covers all capital raising operations in international equity markets by firms for the period 1983 to 2001. Data from the Bank of New York, Euromoney, the London Stock Exchange (LSE), NASDAQ, and the New York Stock Exchange (NYSE) are also used to identify the "international" firms in each country. International firms are those that are listed in international markets, directly or via DRs, or have raised capital in international equity markets. This classification is used to determine the market capitalization of all international firms in each country, which we use as one measure of the level of internationalization. ${ }^{12,13}$

We use nine variables for our analysis, three for the development of local stock markets, three for the internationalization of stock exchange activities, and three for the relative degree of internationalization. The first three are: market capitalization over gross domestic product (GDP), value traded domestically over GDP, and capital raised

\footnotetext{
${ }^{11}$ The list of countries and data sources for both the dependent and independent variables used in our regressions are detailed in Appendix Tables 1 and 2.

12 This measure does not indicate whether the shares of these firms are actively traded in international markets. For some cross-listed stocks, trading is largely in the home market rather than abroad. Also, some stocks might have little free float available for (foreign) investors. Both facts may lead to an overestimation of the degree of internationalization when using this variable. The other measures of level of internationalization, trading and capital raised abroad, do not suffer from these potential biases, since they quantify the actual activity that takes place in international markets. The results using the market capitalization of international firms are similar to those using the variables that capture actual activity abroad, and thus do not alter our conclusions.

${ }^{13}$ For all the internationalization variables (market capitalization of international firms, value traded abroad, and capital raised abroad), observations are assigned a zero when no activity in international equity markets is identified.
} 
domestically over GDP. The next three are: market capitalization of international firms over GDP, value traded abroad over GDP, and capital raised abroad over GDP. The last three are: market capitalization of international firms over total domestic market capitalization, value traded abroad over value traded domestically, and capital raised abroad over capital raised domestically. ${ }^{14}$

\subsection{Capital market reforms}

As mentioned above, we analyze the impact of six capital market-specific and related reforms: stock market liberalization, enforcement of insider trading laws, introduction of fully automated electronic trading systems, privatization programs, structural pension reform, and institutional reform. ${ }^{15}$ While these reforms were a significant part of the capital market reform programs implemented by most countries, this list is not exhaustive and does not attempt to cover all the policy initiatives oriented towards fostering stock market development that were implemented over the last decades. The focus on these reforms is driven by their relevance, as many imply significant policy changes, and by data availability on their implementation dates for a large enough number of countries. Although we believe that we cover some of the most significant capital market related reforms, some policies not included in our analysis due to lack of data may be as relevant, if not more, for stock market development. We now turn to the description of each reform and the data sources.

Stock market liberalization is the decision by a government to allow foreign investors to purchase shares in the local stock market and domestic investors to purchase shares abroad. International asset pricing models predict that the integration with world financial markets should lead to a reduction in the cost of capital. ${ }^{16}$ A number of papers assess the impact of stock market liberalization on the cost of equity capital, finding evidence of an increase in share prices around the liberalization date and a reduction in the cost of capital afterwards. ${ }^{17}$ Other papers analyze the impact of stock market liberalization on real variables, reporting significant increases in investment and economic growth following liberalization. ${ }^{18}$ Regarding stock market development, liberalization increases the pool of capital available to local firms and broadens the investor base. This is likely to lead to increased liquidity and larger amounts of research, improving the quantity and quality of information available to market participants. Furthermore, the scrutiny of foreign investors and analysts may increase transparency and promote the adoption of

\footnotetext{
14 Note that for the domestic activity measures we have data up to 2004, while our data on internationalization end in 2000. As a robustness check, we also estimated all the regressions using domestic variables up to 2000 only and found similar results.

15 Appendix Table 1 lists the dates of the different reforms analyzed.

16 See, for example, Stapleton and Subrahmanyam (1977), Stulz (1981, 1999), Errunza and Losq (1985), Eun and Janakiramanan (1986), and Alexander, Eun, and Janakiramanan (1987).

${ }^{17}$ See, for example, Bekaert and Harvey (2000), Henry (2000a, 2003), Kim and Singal (2000), and Edison and Warnock (2003a).

${ }^{18}$ See, for example, Henry (2000b, 2003) and Bekaert, Harvey, and Lundblad (2005).
} 
better corporate governance practices, reducing agency problems (Stulz, 1999; Errunza, 2001). Therefore, liberalization was expected to result in deeper and more efficient stock markets. Bekaert, Harvey, and Lundblad (2001) find that liberalization had a positive impact on domestic trading and listing. Jain-Chandra (2002) also finds significant increases in trading activity and reports improvements in market efficiency following liberalization. Bae, Bailey, and Mao (2006) find that stock market liberalization improves the information environment in emerging markets. ${ }^{19}$

Our data for dating the liberalization of stock markets come from three sources: Bekaert, Harvey, and Lundblad (2005), who present official liberalization dates, mostly for developing countries; Kaminsky and Schmukler (2003), who construct an index of the extent of stock market liberalization which also includes developed economies; and Vinhas de Souza (2005), who extends this index to Eastern European countries. ${ }^{20} \mathrm{We}$ combine these three sources to get the widest possible coverage. ${ }^{21}$

As part of the capital market reform programs, governments approved new laws and regulations aimed at creating the proper legal and regulatory framework for capital markets to flourish. Many countries tried to improve corporate governance practices, by introducing new standards in a number of different areas, including voting ratings, tender procedures, and the structure of the board of directors. Some countries also enacted new insider trading regulations and improved accounting and disclosure standards. As we mentioned above, the recent literature has emphasized the role of the protection of minority investors for the development of stock markets. Most of the cross-country data available for this variable is time invariant, and therefore cannot be used to analyze the impact of reforms. To account for improvements in the legal framework for investors, we thus focus on the enforcement of insider trading regulations. The date of insider trading laws enforcement is the date of the first prosecution under these laws. These data come from Bhattacharya and Daouk (2002), who carry out a comprehensive survey of insider trading laws, finding that these laws existed in 87 countries by 1998 but had been enforced, as evidenced by prosecutions, in only 38 of them. They also find that the cost of equity does not change after the introduction of insider trading regulations, but decreases considerably after the first prosecution.

Policymakers also took important strides towards establishing and improving the basic environment for capital market operations, including new policies related to

\footnotetext{
${ }^{19}$ Levine and Zervos (1998b) analyze the impact of capital account liberalization on stock market development in 16 developing countries and find evidence of significant increases in market capitalization and trading in most countries.

${ }^{20}$ For the data from Kaminsky and Schmukler (2003) and Vinhas de Souza (2005), we consider the first year when a country's stock market is fully liberalized as the liberalization date. Alternatively, we also used the date of the first partial liberalization and obtained similar results.

${ }^{21}$ Alternatively, we also ran regressions using only the Bekaert, Harvey, and Lundblad (2005) dates and their "First Sign" liberalization measure, which is based on the earliest of three possibilities: the launching of a country fund, an ADR announcement, and the official liberalization date. We obtained similar results using these variables.
} 
centralized exchanges, securities clearance and settlement systems, trading platforms, and custody arrangements. These reforms were expected to improve market performance, by increasing liquidity, enhancing efficiency, and reducing trading costs. We focus our analysis on the replacement of traditional trading floors, on which brokers manually match orders using an open outcry system, by fully automated electronic trading systems. Electronic trading systems may increase liquidity and improve efficiency by reducing transaction costs and increasing information availability. These trading systems may also attract new pools of liquidity, by providing affordable remote access to investors. ${ }^{22}$ The dates of the introduction of electronic trading systems come from Jain (2005), who collects data on stock exchanges in 120 countries and finds that the leading exchanges in 101 of those countries have introduced electronic trading over the last 25 years. ${ }^{23}$ He finds evidence that the introduction of electronic trading systems enhances liquidity and leads to a reduction in the cost of capital.

In the last twenty years, governments from all over the world have undertaken significant privatization programs. Worldwide revenues from privatization soared during the 1990s, peaking in 1998 at over 100 billion U.S. dollars (OECD, 2001). This privatization process was motivated by the desire to increase government revenues, promote economic efficiency, and reduce government interference in the economy (see Megginson and Netter, 2001 for a review of the empirical literature on privatization). Domestic capital market development was also an explicit objective of privatization programs in many countries. Privatizations had a direct impact on domestic stock markets, as many governments carried out privatization sales through share offerings on local exchanges. Due to the positive externalities generated by listing decisions, these share issues were expected to foster stock market development, by increasing the diversification opportunities available to investors and therefore encouraging trading activity and new listings by private firms (Pagano, 1989, 1993). Share issue privatizations (SIPs) could also increase the participation of uninformed retail investors in local stock exchanges, reducing adverse selection in the market and increasing liquidity (Kyle, 1985). ${ }^{24}$ Perotti and van Oijen (2001) argue that privatization programs, even without share offerings on local exchanges, may foster stock market development by reducing political risk and signaling commitment to market-oriented policies. Privatizations also had a direct impact on

\footnotetext{
22 See Domowitz and Steil (1999) for a discussion of the impact of electronic trading on the exchange industry. Blennerhasset and Bowman (1998) report a fall in transaction costs after the move to electronic trading in the New Zealand Stock Exchange. Green et al. (2003) also find improvements in efficiency and liquidity following the introduction of screen-based trading in the Mumbai Stock Exchange.

${ }^{23}$ We consider the introduction of a fully automated system as the relevant change. Jain (2005) finds that in 11 of the exchanges covered in his paper floor trading coexists with electronic trading. We exclude these exchanges from the analysis.

${ }^{24}$ See Chiesa and Nicodano (2003) for a review of the theoretical arguments on the impact of privatization on stock market development. Bortolotti et al. (2004) analyze the impact of SIPs in 19 developed countries and find that they are associated with improvements in turnover and liquidity.
} 
internationalization, as many privatization sales involved offerings in international financial markets. ${ }^{25}$

To date the start of privatization programs we use data from the World Bank privatization database, which records privatization transactions from developing countries between 1988 and 2003, and the Privatization Barometer database, which has data on privatization transactions starting in 1977 for 23 European countries. For some countries not included in these databases, we collected data on privatization transactions from government sources. We define the starting date of a privatization process as the first year with at least two privatization transactions that is followed by further transactions in at least three of the next four years. ${ }^{26} \mathrm{We}$ require privatization activity to be maintained for at least some time because we want to capture the start of a privatization program and not isolated transactions. Also, note that we focus on transactions and not the announcement of a privatization program or the introduction of a privatization law, as we want to capture the actual implementation of a privatization program.

Another significant reform in many countries, especially in Latin America and Eastern Europe, was the shift from public pay-as-you-go pension systems to privately managed funded systems. ${ }^{27}$ Chile was the first country to implement this type of reform in 1981 and several countries adopted similar systems during the 1990s. Structural pension reforms were expected to improve macroeconomic stability, by reducing the demographic pressures of pay-as-you-go systems and inducing fiscal reform during the transition, reduce labor market distortions, increase savings, and reduce political interference in the system. ${ }^{28}$ Pension reform was also seen as conductive for capital market development. As reviewed by Walker and Lefort (2002), pension reform may foster the development of domestic capital markets through three main channels: by inducing authorities to improve the regulatory framework (accumulating "institutional capital"), increasing specialization in the investment decision-making process, and improving incentives for financial innovation. $^{29}$

${ }^{25}$ See Bortolotti, Fantini, and Scarpa (2002) for an analysis of the determinants of privatizations through share offerings in international markets.

${ }^{26}$ For countries that record privatization transactions in 1988 or 1989 in the World Bank privatization database, we use the dates from Perotti and van Oijen (2001).

${ }^{27}$ The nature of the reforms differed across countries, with some countries shifting to fully funded systems of privately managed individual accounts, while others created multipillar systems, in which part of the pension system is pay-as-you-go and there is also a distinct and separate privately managed funded component. See Rutkowski $(1998,2002)$ for a description of the reforms in transition economies. Queisser (1998), De Ferranti, Leipziger, and Srinivas (2002) and Gill, Packard, and Yermo (2005), among many others, review the Latin American experience.

${ }^{28}$ There is a large literature discussing the impact of structural pension reforms. See, for example, World Bank (1994), Feldstein (1998), Orszag and Stiglitz (2001), and Feldstein and Liebman (2002).

${ }^{29}$ Walker and Lefort (2002) find evidence of a reduction in the cost of capital and higher trading volumes as a result of pension reform. Catalan, Impavido, and Musalem (2001) analyze the Granger causality between contractual savings (assets held by pension funds and life insurance companies) and stock market 
To date the implementation of pension reforms we combine data from several sources, including Palacios and Pallares-Millares (2000), the International Association of Pension Funds Supervisory Authorities (AIOS), the International Federation of Pension Funds Administrators (FIAP), and the International Center for Pension Reform. ${ }^{30}$

As discussed above, cross-country evidence on the determinants of stock market development shows that countries with better institutional frameworks tend to have more active stock markets. However, for many developing countries it may be very difficult, if not impossible, to replicate the institutional environment existing in developed countries. Therefore, we focus our analysis on the impact of institutional changes on stock market development and internationalization, not on the absolute quality of institutions. To date institutional improvements we use data from IMF (2005), which analyzes changes in economic institutions for approximately 90 developing countries over the 1970-2004 period. Dates of institutional transitions are based on the evolution of the Cato Institute index of economic freedom, which measures a country's business environment by analyzing five major areas: government size, legal structure and security of property rights, access to sound money, freedom to trade internationally, and regulation of credit, labor, and business (see Gwartney and Lawson, 2004 for a detailed description). ${ }^{31}$ IMF (2005) identifies 65 episodes of sustained transition towards higher economic freedom.

\section{Reforms and stock market development and internationalization}

In this section, we analyze the impact of reforms on domestic stock market development and internationalization using event studies. Since we are interested in the within-country effects of reforms (abstracting from cross-country variations), we estimate fixed-effects regressions of our nine measures of domestic stock market development and internationalization on a dummy for each reform, defined by the reform dates described above. ${ }^{32}$ We concentrate our analysis on a ten-year window around the reform dates (five years before and five years after, including the reform year) and include only those

\footnotetext{
development and find evidence that the growth in contractual savings causes increases in market capitalization and trading.

${ }^{30}$ Pension reforms in Australia, Denmark, the Netherlands, and Switzerland involved adding a tier to an existing system or converting a voluntary funded scheme into a mandatory one. In contrast, the reforms in the remaining countries represented major changes, shifting from publicly managed unfunded schemes to multipillar systems or to completely privately managed funded schemes. Given the difference in the nature of the reforms, we also estimated our regressions excluding Australia, Denmark, the Netherlands, and Switzerland and obtained similar results.

${ }^{31}$ The index of economic freedom ranges from one (repressed) to ten (free). IMF (2005) defines the start of an institutional transition in a country as the first year in which the forward looking eight-year moving average of this index exceeds by at least one point its backward looking eight-year moving average and reaches a minimum level of four points. The list of transitions was reviewed by IMF country desks and adjusted where appropriate.

${ }^{32}$ The reform dummy equals one on and after the date of reform, and zero before.
} 
countries with at least two annual observations before and after the implementation of the reforms. $^{33}$

Regression results for the domestic development variables, the foreign activity variables, and the ratio of international to domestic activity are presented in Tables 1, 2, and 3, respectively. Each column reports the results for a specific reform. Note that the sample of countries and the period covered varies across columns, as only those countries that implemented the reform under analysis are included in each regression and the period analyzed changes according to the reform date for each country.

The estimations on market capitalization over GDP (Table 1, top panel) show that all the reform coefficients are positive and significant at the one percent level. Furthermore, the size of these coefficients is quite large. In the case of stock market liberalization, for example, the pre-reform average stock market capitalization over GDP is 19.3 percent and the within-country difference between the pre-liberalization and postliberalization periods is 14.2 percentage points.

Similar results are found for value traded domestically (middle panel) and capital raised domestically (bottom panel). All the reforms, with the exception of stock market liberalization, seem to be followed by increased trading activity in the local market. In the case of capital raised, only pension reform is not significant.

Reforms also seem to be associated with increases in stock market internationalization. All the reforms under analysis are followed by significant increases in the market capitalization of international firms over GDP (Table 2, top panel). Trading abroad (middle panel) and capital raised abroad (bottom panel) also increase after the implementation of reforms. Pension reform is significant only at the ten percent level for trading abroad and is not statistically significant in the case of capital raised in international markets.

These results show that reforms are followed by increased domestic stock market development and internationalization. This suggests that reforms may make local firms more attractive to foreign investors, who then grant them access to international markets at attractive terms. This evidence is consistent with the findings of Claessens, Klingebiel, and Schmukler (2006), who report that better fundamentals foster stock market development, but also increase internationalization. Some of the results may also reflect

\footnotetext{
${ }^{33}$ By focusing on a ten-year window around the reforms we may not be capturing their whole impact if they take more than five years to mature. However, while in traditional event studies the econometrician can be certain that the event under analysis is isolated, capital market reforms often coincide with other macroeconomic and institutional reforms. By focusing on a shorter event window we attempt to isolate from other changes that may also affect stock market development and internationalization. We discuss this issue in more detail in Section 4. We also tried the regressions without restricting the sample period to a preset window (i.e., including all available observations) and using a shorter six-year window, and obtained similar results in both cases. We also estimated the regressions including only countries with at least three years of data available before and after the reforms and obtained similar results. However, for some reforms and dependent variables this reduces significantly the number of countries.
} 
the direct impact of reforms. In the case of privatization, for example, as we mention above, some firms were privatized through public offerings in international markets. This should have a direct effect on the three internationalization variables analyzed.

A relevant question is whether the reforms are followed by similar increases in domestic and international activity. The evidence presented so far does not allow us to answer this question because the samples used for the regressions on domestic and international variables (relative to GDP) are different, due to data availability. Therefore, we analyze the impact of reforms on the ratio of international to domestic activity, which constraints the sample to be the same. These results are presented in Table 3.

The results for the ratio of the market capitalization of international firms to total domestic market capitalization (Table 3, top panel), suggest that reforms are followed by an acceleration in the internationalization process. All the reform coefficients are positive and significant at the one percent level. Furthermore, the size of the coefficients is quite large. The regressions on value traded abroad over value traded domestically (middle panel) present similar results. All the reforms, with the exception of privatization and the introduction of electronic trading systems, seem to be followed by large increases in the share of trading that takes place in international markets. ${ }^{34}$

Finally, for the ratio of capital raised abroad to capital raised domestically (bottom panel), the results show that stock market liberalization, privatization, and institutional reform are associated with a larger share of activity in international markets. The rest of the reforms are not statistically significant. This may reflect the fact that this ratio is quite lumpy and fluctuates widely from year to year, depending on individual equity issues. Alternatively, the lack of significance of the reform dummies may just indicate that the reforms are followed by similar changes in domestic and international capital raising, leaving the ratio unchanged.

In sum, our results show that capital market reforms are followed by significant increases in domestic stock market activity and internationalization. Furthermore, they seem to be associated with a larger share of activity in international markets. Although our regressions show a statistically significant correlation between reforms and stock market activity, both domestically and abroad, there are a number of arguments that suggest that these results should be interpreted with care and that it is difficult to show a causal link between reforms and market activity. We now turn to those arguments and present some robustness tests.

\footnotetext{
${ }^{34}$ In the case of privatization, the results are driven by two countries (the Netherlands and South Africa) that experienced very large increases in domestic trading after the reform, which translated into a lower ratio of value trade abroad to value traded domestically. If we exclude these two countries, the coefficient on privatization is positive and significant at the one percent level.
} 


\section{Robustness tests and alternative explanations}

A possible explanation for the positive relation we find between reforms and stock market activity is that it is driven by some omitted variables that are correlated with reforms, but not by the reforms themselves. For instance, countries may time their reforms to coincide with high points in the world business cycle. That is, there might be common factors. ${ }^{35}$ In this case, our results may overstate the impact of reforms, since the reform dummies may be capturing the effect of the international business cycle on stock market activity. This may be particularly relevant for some reforms, such as stock market liberalization and privatization, as governments have incentives to liberalize and privatize when they face favorable international conditions and therefore expect valuations to be higher.

As another example of omitted factors, capital market reforms are often part of larger macroeconomic and institutional reform programs. Mathieson and Rojas-Suarez (1993) and Henry (2000b) discuss how policy reforms in developing countries often involve macroeconomic reforms, including trade liberalization, macroeconomic stabilization programs, and the easing of exchange rate controls. These policies may have a significant impact on growth prospects and might lead to increased stock market activity, both domestically and abroad. Our reform dummies may thus be capturing the impact of the contemporaneous macroeconomic and institutional changes, and not that of the capital market reform analyzed in each case.

To address these concerns, we reestimate the regressions from Tables 1, 2, and 3 controlling for additional variables. In particular, we include U.S. interest rates and GDP growth in high-income OECD countries to control for the world business cycle. ${ }^{36}$ To capture the impact of contemporaneous macroeconomic reforms, we do not use reform dummies, as we do not have sufficient information to date these reforms for all the countries in our dataset. Therefore, we follow an indirect approach, by controlling for domestic fundamentals that may capture the outcome of these reforms. Specifically, we control for GDP growth and the fiscal deficit. ${ }^{37}$ Note that GDP growth may also be

\footnotetext{
35 The international finance literature has highlighted to the role of global factors, such as interest rates and growth, in explaining capital flows to emerging markets (see, for example, Calvo, Leiderman, and Reinhart, 1993; Fernandez-Arias, 1996; and Edison and Warnock, 2003b). Albuquerque, Loayza, and Servén (2005) find that these common factors are increasingly important in the case of foreign direct investment.

${ }^{36}$ We also estimated the regressions using, alternatively, U.S., world, and G-7 GDP growth and obtained similar results. As a measure of U.S. interest rates, we use the rate on three-year Treasury bonds. We also ran the regressions using the rates on five-year Treasury bonds and three-month Treasury bills, the federal funds rate, and the S\&P 500 annual return. The results using these variables are similar to the ones reported below. We also included the change in the terms of trade in each country as an independent variable, to control for external shocks, and obtained similar results.

${ }^{37} \mathrm{We}$ also estimated the regressions using other proxies for reforms, such as inflation, trade (exports plus imports) as a percentage of GDP, and the International Country Risk Guide composite index, which measures political, economic, and financial conditions in a country. Including these variables does not affect our main results. We also controlled for each country's growth prospects, as measured by the growth opportunities index developed by Bekaert et al. (2006), and obtained results similar to those reported here.
} 
interpreted as a measure of the domestic business cycle, which may also affect the timing of capital market reforms.

Tables 4, 5, and 6 present the results of the regressions on domestic stock market development, internationalization, and the ratio of international to domestic activity, respectively. For each reform, we present two specifications: the first one only includes the reform dummies and domestic macroeconomic variables, while the second one also controls for those variables that proxy for the world business cycle. ${ }^{38}$

The regressions on stock market capitalization over GDP (Table 4, top panel) show that our results are robust to controlling for macroeconomic variables and the international business cycle. All the reform coefficients are positive and statistically significant at the one percent level. Most of the coefficients are lower than those reported in Table 1, which suggests that in those regressions our reform dummies may be capturing part of the positive impact of macroeconomic reforms and the international business cycle on domestic market capitalization. Regarding the remaining variables, the coefficients on fiscal deficit over GDP are negative and statistically significant while those on GDP growth tend to be positive and significant. We also find that the international business cycle affects domestic stock markets, with higher U.S. interest rates and lower OECD growth resulting in lower market capitalizations.

The results for value traded domestically (middle panel) are similar, with all reform coefficients being positive and significant, except for those on stock market liberalization, consistent with the results reported in Table 1. In the case of capital raised domestically over GDP (bottom panel), all the reforms are statistically significant, with the exception of pension reform, in line with the results in Table 1.

The results in Table 5 show that reforms tend to be followed by increased capitalization, trading, and capital raising in international markets, even when controlling for macroeconomic variables and the international business cycle. In the case of the market capitalization of international firms over GDP (top panel), all the reform coefficients are positive and statistically significant. The results for value traded abroad (middle panel) are similar. Only the introduction of electronic trading systems and pension reform are not statistically significant in the specifications that include all the control variables. The results for capital raised abroad (bottom panel) are consistent with those reported in Table 2, with all reforms being followed by significant increases in capital raising in international equity markets, except for pension reform.

Furthermore, we controlled for GDP per capita since general economic and institutional development may affect the evolution of stock markets and the effect of reforms. The results remain mostly unchanged.

${ }^{38}$ The fiscal deficit over GDP variable is not available for all countries and periods; therefore in these regressions we have a smaller number of observations than in Tables 1,2, and 3. We also estimated the regressions controlling only for GDP growth, which allows us to use all the available observations, and obtained similar results. 
Finally, the results reported in Table 6 show that reforms tend to be followed by an increased share of market capitalization and trading in international markets. In the case of the market capitalization of international firms over total domestic market capitalization (top panel), all the reform dummies are positive and statistically significant at the one percent level, except for institutional reform when controlling for the international business cycle. For the ratio of value traded abroad to value traded domestically (middle panel), all the reform coefficients are positive and statistically significant, with the exception of those on the introduction of electronic trading systems and privatization. However, when controlling for international growth and interest rates the enforcement of insider trading laws and institutional reform lose their significance. For capital raised abroad over capital raised domestically, the coefficients on stock market liberalization, the introduction of electronic trading systems, privatization, and institutional reform are positive and significant when controlling only for domestic variables, but tend to lose their significance when we also include the variables that proxy for the international business cycle. The remaining reform coefficients are not significant. These results may be due to the lumpy nature of this ratio and to the fact that firms may raise relatively more equity in international markets when conditions in those markets are better. In this case, the international business cycle indicators may be capturing most of the time variation of this variable. Alternatively, the results may just mean that reforms are followed by similar increases in capital raised domestically and abroad.

The evidence presented in Tables 4, 5, and 6 shows that the positive correlation between capital market reforms and stock market development and internationalization is robust to a number of potential omitted variables, but should still be interpreted with caution. Although in these regressions we attempt to control for a number of contemporaneous macroeconomic and institutional reforms, we may not be capturing all the reforms and their complete impact. Some of these reforms may be pre-requisites for successful capital market reforms. We may also be omitting other relevant variables that drive the processes of domestic stock market development and internationalization. To the extent that our reform dummies inadvertently capture the effect of these variables, we may be overstating the impact of reforms.

All the analyses presented above have focused on measuring the impact of each reform, without taking into account other capital market reforms. However, countries tend to implement several capital market reforms in a relatively short period of time. In fact, our data show that 26 countries in our sample (about 40 percent of those with data available on all of the six reforms under analysis) have implemented at least three capital market reforms in a five-year period. Thus, the reform dummies in our regressions may not be capturing the marginal effect of each reform, but rather the impact of other capital market reforms implemented around the same date. Also, the literature suggests that the different capital market reforms may be closely interrelated. For instance, Rajan and Zingales (2003) argue that openness to capital flows may reduce the power of incumbents who oppose reforms that foster financial development. Similarly, Walker and Lefort (2002) argue that pension reform may prompt improvements in securities market regulations. This suggests that capital market reforms may not be independent of each 
other. Although we try to measure the impact of each reform separately, what may matter most for stock market development is a comprehensive set of reforms and not the implementation of isolated reforms.

To measure the marginal effect of each reform, we reestimate our regressions controlling for the number of capital market reforms implemented by each country, other than the reform under analysis in each case. ${ }^{39,40}$ This variable captures the impact of additional capital market reforms clustered around the reform being analyzed (i.e., reforms implemented more than five years before or after the reform under study do not affect our results). Given that we control for country-level fixed effects, our results are not affected by differences across countries in the number of reforms implemented. To keep the number of tables at a manageable level, we only report the results without including additional control variables and excluding the capital raising measures given their lumpy nature. ${ }^{41}$ The results are presented in Table 7.

The top panel in Table 7 shows the regressions for the domestic stock market development variables. Most of our results are robust to controlling for the implementation of additional capital market reforms. All the reforms, except for the enforcement of insider trading laws, are followed by significant increases in market capitalization over GDP. Similar results are found for value traded domestically over GDP. All the reforms, with the exception of stock market liberalization and institutional reform, are followed by increased trading activity in the local market. Most of the coefficients are lower than those reported in Table 1, which suggests that in those regressions our reform dummies may be capturing part of the effect of other capital market reforms clustered around that time. The results also show that the number of additional reforms tends to be positive and statistically significant.

Reforms also seem to be associated with increases in stock market internationalization, even when controlling for other capital market reforms (middle panel). All the reforms under analysis are followed by significant increases in the market capitalization of international firms over GDP. Trading abroad also increases after the

\footnotetext{
${ }^{39}$ This variable is calculated by adding up the different reform dummies, other than that for the reform under analysis in each case. This requires having information to determine whether countries implemented all of the six reforms analyzed in this paper or not. Therefore, the sample of countries included in these regressions is restricted to countries with data available on all capital market reforms. As an alternative, we estimated the regressions assuming that those countries with missing data on a reform did not implement it and obtained similar results.

${ }^{40}$ We use the number of additional reforms to control for contemporaneous reforms and not one dummy for each reform because the different reform dummies tend to be highly correlated. As an alternative, we also estimated the regressions including only those countries that implemented specific reforms in relative isolation from other capital market reforms. If our reform dummies are only capturing the effect of implementing a comprehensive capital market reform package, and not the impact of individual reforms, one would expect those countries that implemented isolated reforms to experience no significant change in stock market activity. However, our results indicate that even in those countries, most reforms are followed by significant increases in stock market activity both at home and abroad.

${ }^{41}$ In most cases, similar results are obtained when controlling for domestic macroeconomic variables.
} 
implementation of reforms, only the introduction of electronic trading systems and pension reform are not statistically significant. The results also show that the number of additional reforms tends to be positive and significant.

Finally, the results for the share of international activity (bottom panel) suggest that reforms are followed by an acceleration in the internationalization process. In the regressions of the ratio of the market capitalization of international firms to total domestic market capitalization, all the reform coefficients enter positively and significantly, except for that on institutional reform. The results also indicate that the enforcement of insider trading laws and pension reform are followed by significant increases in value traded abroad over value traded domestically.

In sum, the results reported in Table 7 suggest that the reform dummies in our regressions are not just capturing the effect of implementing a capital market reform package (i.e., several reforms in a short period of time), but rather that the reforms analyzed have a positive marginal impact on stock market development and internationalization. It would be interesting to explore whether certain reforms tend to complement each other and if differences in the timing of specific reforms affect their impact on stock market development and internationalization, but this exceeds the objectives of this paper.

A difficult question concerning our results is whether the reform dummies are estimating the effect of some underlying trend not captured by the controls already included in the regressions. To the extent that there are some remaining omitted factors that drive the processes of stock market development and internationalization over time, the reform variables could be capturing the impact of those omitted factors. Most of the reforms took place in the first half of the 1990s and the post-reform period coincides with strong global trends towards financial development and internationalization, posing a challenge to the accurate identification of the marginal effect of reforms. With the available data, there is no easy answer to this question.

To try to address this issue, we reestimated our regressions controlling for time effects to capture any omitted factors that vary with time. But given the short time series available for the post-reform period and the presence of strong trends, including time effects in our regressions is likely to weaken the impact and significance of the reform dummies, even if reforms had a positive effect on stock market activity. Therefore, these results could be interpreted as a lower bound measure of the effect of reforms. Conversely, the results without controlling for time effects could be interpreted as an upper bound measure of the impact of reforms, as they assign the impact of any underlying trend to the reforms.

Several issues emerge when including a trend. An important question that arises is whether these time effects are similar across countries and regions. The data suggest that the evolution of stock markets over the last decades has differed among developed and developing countries, therefore we include a common time trend across all countries and 
the interaction between this time trend and a dummy variable that equals one for developing countries and zero for developed ones. Moreover, to be able to accurately estimate these time trends and differentiate them from the effect of reforms, we include all the years for which we have data available on the dependent variables in these regressions (we do not restrict the sample to a ten-year window around the reform dates). We also include all countries with data on the dependent variables, irrespective of whether they implemented the reform under analysis, to obtain better estimates of the time effects. ${ }^{42} \mathrm{We}$ present results only for the domestic stock market development variables, as we have a significantly shorter time series for internationalization variables, which makes it very difficult to separate the effect of a time trend from that of the reforms. To keep the number of tables at a manageable level, we only present the results without including additional controls. ${ }^{43}$ The results are presented in Table 8.

The results for stock market capitalization over GDP (top panel) show that, even when controlling for time effects, some of the reforms remain statistically significant. In particular, the enforcement of insider trading laws, privatization, and pension reform are followed by significant increases in market capitalization. Regarding the time effects, the results show that there is a positive and significant trend, but this trend is lower (although still positive) in the case of developing countries. ${ }^{44}$

The results for both value traded domestically (middle panel) and capital raised domestically (bottom panel) also show that some capital market reforms are followed by significant increases in domestic activity, even when controlling for time effects. In particular, the enforcement of insider trading laws, the introduction of electronic trading systems, and institutional reform are all statistically significant and positive in the regressions of value traded domestically over GDP. In the case of capital raised domestically, the introduction of electronic trading systems and privatization are both significant at the one percent level.

In sum, even with the difficulty of separating the two effects mentioned above, the finding that some reforms remain positive and significant in Table 8 suggests that our reform dummies are not just capturing the effects of some underlying trend, but rather that these reforms were associated with the development of domestic stock markets. In the case of internationalization, separating the impact of a common time trend from that of reforms would require longer time series of our dependent variables.

\footnotetext{
42 The sample in these regressions is restricted to those countries for which we have information to determine whether they implemented the reform under analysis in each case or not. As an alternative, we estimated the regressions assuming that those countries with missing data on a reform did not implement it and obtained similar results in most cases.

43 In most cases, similar results can be obtained when controlling for domestic and international macroeconomic variables.

44 The time trend for developing countries is equal to the sum of both the common time trend and the trend interacted with the developing country dummy. This time effect is positive and statistically different from zero at the one percent level in all specifications.
} 
Finally, an important question is whether the reform decision is really exogenous or if countries implement reforms when they expect their stock markets to do well. If this were the case, causality would run in the opposite direction. We believe that endogeneity could potentially be relevant for some of the reforms analyzed, but in any case does not affect our results on internationalization. In other words, endogeneity arguments usually refer to domestic stock market development, as countries may implement reforms when they anticipate increased local market activity. It is less likely that reforms are implemented in response to expected increases in internationalization. Moreover, many of the reforms analyzed, such as privatization, institutional reform, and pension reform, constitute major policy initiatives and therefore it is unlikely that they were driven by (expected) changes in stock market activity. On the other hand, endogeneity could affect our results on the impact of capital market-specific reforms on domestic market development, as countries have incentives to invest in new trading platforms or enforce insider trading regulations when they expect increased local stock market activity. In sum, we think that even though endogeneity could be present, it would affect only a small part of our results and would not alter our main conclusions.

\section{Conclusions}

In this paper, we analyze the impact of capital market-specific and related reforms on stock market development and internationalization. Our empirical analysis shows that these reforms are followed by increases in capitalization, trading, and capital raising in the local market. The evidence thus suggests that reforms are positively related to domestic stock market development, contrary to the claim that they are not effective and that the variation in panel data studies comes only from cross-country differences. However, we also find that internationalization increases after reforms, relative to both GDP and domestic market activity. This runs contrary to the view that a poor domestic environment prompts firms to access international markets and that reforms reduce incentives to migrate abroad. Rather, it supports the hypothesis that reforms make local firms more attractive, allowing them to access international markets.

Our results come with some caveats. Reforms may be timed to coincide with high points in the domestic and/or international business cycles and with the implementation of other reforms. To address these issues, we control for domestic macroeconomic variables, U.S. interest rates, and output growth in OECD countries. We find our results to be robust to the inclusion of these variables. However, these controls may not capture the full impact of other reforms and/or the business cycle. Also, some prior macroeconomic and institutional reforms may be necessary for capital market reforms to be successful. Furthermore, our reform dummies could be capturing the impact of some underlying trend driving the processes of stock market development and internationalization, not captured by the controls included in the regressions. We try to address this issue by controlling for time effects in the regressions of domestic stock market development and find that some of the reform dummies remain statistically significant and positive, suggesting that capital market reforms are associated with increases in domestic stock market activity beyond any underlying trend. But accurately separating the impact of a common time trend from that 
of reforms would require longer time series of our dependent variables. Thus, more future research in this direction would be welcome.

Our conclusions should thus remain tentative. But they do suggest that reforms do not result in a lower level of activity abroad and a concentration of stock market activity in the domestic market, as some arguments predict. Our findings also suggest that financial globalization could pose a significant challenge to policymakers, as their efforts to foster domestic stock market development seem to translate into more activity abroad. The migration of trading to international markets may adversely affect the liquidity of those firms that remain in the local market and their ability to raise new equity capital. This could have a significant impact on medium sized firms, which are not able to directly access international markets. The unexpected impact of reforms on internationalization calls for a revision of the reform agenda and related expectations. Further research is necessary to understand whether the impact of reforms differs across countries and regions and if differences in the timing of specific reforms affect their impact on stock market development and internationalization. ${ }^{45}$

\footnotetext{
${ }^{45}$ Some of the cross-regional differences are already studied in de la Torre and Schmukler (2006) and de la Torre, Gozzi, and Schmukler (2006).
} 


\section{References}

Albuquerque, R., Loayza, N., Servén, L., 2005. World market integration through the lens of foreign direct investors. Journal of International Economics 66, 267-295.

Alexander, G., Eun, C., Janakiramanan, S., 1987. Asset pricing and dual listing on foreign capital markets: A note. Journal of Finance 42, 151-158.

Atje, R., Jovanovic, B., 1993. Stock markets and development. European Economic Review 37, 632-640.

Bae, K., Bailey, W., Mao, C. X., 2006. Stock market liberalization and the information environment. Journal of International Money and Finance 25, 404-428.

Bagehot, W., 1873. Lombard Street. Richard D. Irwin, Homewood, IL (1962 Edition).

Bekaert, G., Harvey, C. R., 2000. Foreign speculators and emerging equity markets. Journal of Finance 55, 565-613.

Bekaert, G., Harvey, C. R., Lundblad, C., 2001. Does financial liberalization spur growth? NBER Working Paper No. 8245.

Bekaert, G., Harvey, C. R., Lundblad, C., 2005. Does financial liberalization spur growth? Journal of Financial Economics 77, 3-55.

Bekaert, G., Harvey, C. R., Lundblad, C., Siegel, S., 2006. Global growth opportunities and market integration. Journal of Finance, forthcoming.

Benos, E., Weisbach, M. S., 2004. Private benefits and cross-listings in the United States. Emerging Markets Review 5, 217-240.

Bhattacharya, U., Daouk, H., 2002. The world price of insider trading. Journal of Finance 57, 75-108.

Blennerhassett, M., Bowman, R. G., 1998. A change in market microstructure: The switch to electronic screen trading on the New Zealand Stock Exchange. Journal of International Financial Markets, Institutions and Money 8, 261-276.

Bortolotti, B., de Jong, F., Nicodano, G., Schindele, I., 2004. Privatization and stock market liquidity. Centre for Economic Policy Research (CEPR) Discussion Paper No. 4449.

Bortolotti, B., Fantini, M., Scarpa, C., 2002. Why do governments privatize abroad? International Review of Finance 3, 131-161.

Boyd, J. H., Levine, R., Smith, B. D., 2001. The impact of inflation on financial sector performance. Journal of Monetary Economics 47, 221-248.

Calvo, G., Leiderman, L., Reinhart C., 1993. Capital inflows and real exchange rate appreciation in Latin America: The role of external factors. IMF Staff Papers 40, 108-151.

Catalan, M., Impavido, G., Musalem, A. R., 2001. Contractual savings or stock market development: Which leads? Journal of Applied Social Science Studies 120, 445-487.

Chiesa, G., Nicodano, G., 2003. Privatization and financial market development: Theoretical issues. Fondazioni Eni Enrico Mattei (FEEM) Working Paper No. 1.2003 . 
Claessens, S., Klingebiel, D., Schmukler, S., 2006. Stock market development and internationalization: Do economic fundamentals spur both similarly? Journal of Empirical Finance 13, 316-350.

Collier, P., Hoeffler, A., Pattillo, C., 2000. Flight capital as portfolio choice. World Bank Economic Review 15, 55-80.

De Ferranti, D., Leipziger, D., Srinivas, P.S., 2002. The future of pension reform in Latin America. Finance and Development 39, 39-43.

De la Torre, A., Schmukler, S., 2006. Emerging Capital Markets and Globalization: The Latin American Experience. Forthcoming, Stanford University Press, Stanford. Previously released as Whither Latin American Capital Markets? World Bank, Washington, DC.

De la Torre, A., Gozzi, J., Schmukler, S., 2006. Capital market development: Whither Latin America? Forthcoming in: Edwards, S., Garcia, M. (eds.), Financial Markets Volatility and Performance in Emerging Markets. IASE/NBER Volume, University of Chicago Press, Chicago.

Domowitz, I., Steil, B., 1999. Automation, trading costs, and the structure of the trading services industry. Brookings-Wharton Papers on Financial Services 2, 33-92.

Easterly, W., 2001. The lost decades: Developing countries' stagnation in spite of policy reform 1980-1998. Journal of Economic Growth 6, 135-157.

Edison, H., Warnock, F. E., 2003a. A simple measure of the intensity of capital controls. Journal of Empirical Finance 10, 81-103.

Edison, H., Warnock, F. E., 2003b. Cross-border listings, capital controls, and equity flows to emerging markets. International Finance Discussion Papers 2003-770, Federal Reserve Board.

Errunza, V., 2001. Foreign portfolio equity investments, financial liberalization, and economic development. Review of International Economics 9, 703-726.

Errunza, V., Losq, E., 1985. International asset pricing under mild segmentation: Theory and tests. Journal of Finance 40, 105-124.

Eun, C., Janakiramanan, S., 1986. A Model of international asset pricing with a constraint on foreign equity ownership. Journal of Finance 41, 897-914.

Feldstein, M., 1998. Privatizing Social Security. Chicago University Press, Chicago.

Feldstein, M., Liebman, J., 2002. Social security, in: Auerbach, A., Feldstein, M. (eds.), The Handbook of Public Economics, Volume 4. Elsevier Science, North Holland.

Fernandez-Arias, E., 1996. The new wave of private capital inflows: Push or pull? Journal of Development Economics 48, 389-418.

Gill, I., Packard, T., Yermo, J., 2005. Keeping the Promise of Old-Age Income Security in Latin America. Stanford University Press, Palo Alto.

Green, C, Mannos, R., Murinde, V., Suppakitjarak, J., 2003. The impact of microstructure innovations in emerging stock markets: Evidence from Mumbai, India. Loughborough University, mimeo.

Gwartney, J., Lawson, R., 2004. Economic Freedom of the World: 2004 Annual Report. The Fraser Institute, Vancouver. 
Henry, P. B., 2000a. Stock market liberalization, economic reform, and emerging market equity prices. Journal of Finance 55, 529-564.

Henry, P. B., 2000b. Do stock market liberalizations cause investment booms? Journal of Financial Economics 58, 301-334.

Henry, P. B., 2003. Capital account liberalization, the cost of capital, and economic growth. American Economic Review 93, 91-96.

Inter-American Development Bank, 1995. Overcoming Volatility. Report on Economic and Social Progress in Latin America. Washington, DC.

International Monetary Fund, 2005. World Economic Outlook, September 2005. Washington, DC.

Jain-Chandra, S., 2002. The impact of stock market liberalization on the efficiency of emerging stock markets. Columbia University, mimeo.

Jain, P. K., 2005. Financial market design and the equity premium: Electronic versus floor trading. Journal of Finance 60, 2955-2985.

Kaminsky, G., Schmukler, S., 2003. Short-run pain, long-run gain: The effects of financial liberalization. NBER Working Paper No. 9787.

Karolyi, G. A., 2004. The role of American Depositary Receipts in the development of emerging equity markets. Review of Economics and Statistics 86, 670-690.

Kim, E. H., Singal, V., 2000. Opening up of stock markets: Lessons from emerging economies. Journal of Business 73, 25- 66.

King, R. G., Levine, R., 1993. Finance and growth: Schumpeter might be right. Quarterly Journal of Economics 108, 717-737.

Kyle, A. 1985. Continuous auctions and insider trading. Econometrica 53, 1315-1336.

La Porta, R., Lopez de Silanes, F., Shleifer, A., 2006. What works in securities laws? Journal of Finance 61, 1-32.

La Porta, R., Lopez-de-Silanes, F., Shleifer, A., Vishny, R. W., 1997. Legal determinants of external finance. Journal of Finance 52, 1131-1150.

La Porta, R., F. Lopez-de-Silanes, A. Shleifer, and R. W. Vishny, 1998. Law and finance. Journal of Political Economy 106, 1113-1155.

Levine, R., 1997. Financial development and economic growth: Views and agenda. Journal of Economic Literature 35, 688-726.

Levine, R., 2005. Finance and growth: Theory and evidence, in: Aghion, P., Durlauf, S. (eds.), Handbook of Economic Growth. Elsevier Science, The Netherlands.

Levine, R., Schmukler, S., 2006a. Migration, spillovers, and trade diversion: The impact of internationalization on domestic stock market liquidity. Journal of Banking \& Finance, forthcoming.

Levine, R., Schmukler, S., 2006b. Internationalization and stock market liquidity. Review of Finance 10, 153-187.

Levine, R., Zervos, S., 1998a. Stock markets, banks, and economic growth. American Economic Review 88, 537-558.

Levine, R., Zervos, S., 1998b. Capital control liberalization and stock market development. World Development 26, 1169-1184. 
Mathieson, D. J., Rojas-Suarez, L., 1993. Liberalization of the capital account: Experiences and issues. IMF Occasional Paper No. 103.

Megginson, W. L., Netter, J., 2001. From state to market: A survey of empirical studies on privatization. Journal of Economic Literature 39, 321-389.

Moel, A., 2001. The role of American Depositary Receipts in the development of emerging markets. Economia 2, 209-273.

Organization of Economic Cooperation and Development (OECD), 2001. Recent privatization trends in OECD countries. Paris, France.

Orszag, P., Stiglitz, J., 2001. Ten myths of pension reform, in Holzmann, R. Stiglitz, J. (eds.), New Ideas about Old-Age Security. World Bank, Washington, DC.

Palacios, R., Pallares-Millares, M., 2000. International patterns of pension provision. World Bank Social Protection Discussion Paper No. 0009.

Pagano, M., 1989. Endogenous market thinness and stock price volatility. Review of Economic Studies 56, 269-287.

Pagano, M., 1993. The floatation of companies and the stock market: A coordination failure model. European Economic Review 37, 1101-1125.

Perotti, E., van Oijen, P., 2001. Privatization, political risk, and stock market development in emerging economies. Journal of International Money and Finance 20, 43-69.

Queisser, M., 1998. Pension reform: Lessons from Latin America. Policy Brief 15, OECD Center.

Rajan, R. G., Zingales, L., 2003. The great reversals: The politics of financial development in the 20th century. Journal of Financial Economics 69, 5-50.

Rodrik, D., 1998. Who needs capital-account convertibility? In: Kenen, P. (ed.), Should the IMF Pursue Capital Account Convertibility? Essays in International Finance no. 207. Princeton University Press, Princeton.

Rutkowski, M., 1998. A new generation of pension reforms conquers the East: A taxonomy in transition economies. Transition 9, 16-19.

Rutkowski, M., 2002. Pensions in Europe: Paradigmatic and parametric reforms in EU accession countries in the context of EU pension system changes. Journal of Transforming Economies and Societies 9, 2-26.

Schumpeter, J. A., 1912. Theorie der Wirtschaftlichen Entwicklung. Dunker \& Humblot, Leipzig [The Theory of Economic Development, translated by Redvers Opie. Harvard University Press, Cambridge, MA 1934.]

Stapleton, R., Subrahmanyam, M., 1977. Market imperfections, capital market equilibrium, and corporate finance. Journal of Finance 32, 307-319.

Stiglitz, J., 2000. Capital market liberalization, economic growth, and instability. World Development 28, 1075-1086.

Stulz, R., 1981. On the effects of barriers to international asset pricing. Journal of Finance 25, 783-794.

Stulz, R., 1999. Globalization, corporate finance and the cost of capital. Journal of Applied Corporate Finance 12, 8-25. 
Vinhas de Souza, L., 2005. Financial liberalization and business cycles: The experience of the new EU member states, in: Batten, J., Kearney, C. (eds.), Emerging European Financial Markets: Independence and Integration Post-Enlargement. Elsevier, The Netherlands.

Wacziarg, R., Horn Welch, K., 2003. Trade liberalization and growth: New evidence. NBER Working Paper No. 10152.

Walker, E., Lefort, F., 2002. Pension reform and capital markets: Are there any (hard) links? World Bank Social Protection Discussion Paper 24082.

World Bank, 1994. Averting the Old-Age Crisis: Policies to Protect the Old and Promote Growth. Oxford University Press, New York. 
Table 1

\section{Reforms and Domestic Stock Market Development}

This table shows least square regressions with robust standard errors estimated using fixed effects models for countries implementing reforms between 1975 and 2004. The regressions consider a ten-year event window around the reform dates (five years before and five years after, including the reform year). The sample includes only countries with at least two observations before the reform date and two afterwards. Absolute values of t-statistics are in brackets. *,**, and *** mean significance at ten, five, and one percent, respectively. See Appendix Table 2 for the definition of the variables.

\begin{tabular}{|c|c|c|c|c|c|c|}
\hline \multicolumn{7}{|c|}{ Market Capitalization / GDP } \\
\hline & $(1)$ & $(2)$ & (3) & (4) & (5) & $(6)$ \\
\hline Stock market liberalization & $\begin{array}{r}0.142 \\
{[10.050]}\end{array}$ & & & & & \\
\hline Introduction of electronic trading systems & & & $\begin{array}{r}0.159 \\
{[5.305]}\end{array}$ & & & \\
\hline Pension reform & & & & & & $\begin{array}{l}0.153 \text { *** } \\
{[4.315]}\end{array}$ \\
\hline Country fixed effects & Yes & Yes & Yes & Yes & Yes & Yes \\
\hline No. of observations & 438 & 315 & 582 & 392 & 302 & 211 \\
\hline \multicolumn{7}{|c|}{ Value Traded Domestically / GDP } \\
\hline & $(1)$ & $(2)$ & (3) & (4) & $(5)$ & $(6)$ \\
\hline Stock market liberalization & $\begin{array}{r}0.024 \\
{[0.830]}\end{array}$ & & & & & \\
\hline Enforcement of insider trading laws & & $\begin{array}{r}0.270 \\
{[5.447]}\end{array}$ & & & & \\
\hline Introduction of electronic trading systems & & & $\begin{array}{r}0.171 \\
{[6.127]}\end{array}$ & & & \\
\hline Privatization & & & & $\begin{array}{r}0.087 \\
{[5.623]}\end{array}$ & & \\
\hline Institutional reform & & & & & $\begin{array}{r}0.066 \\
{[3.853]}\end{array}$ & \\
\hline Pre-reform average of dependent variable & 0.108 & 0.196 & 0.073 & 0.051 & 0.065 & 0.171 \\
\hline
\end{tabular}

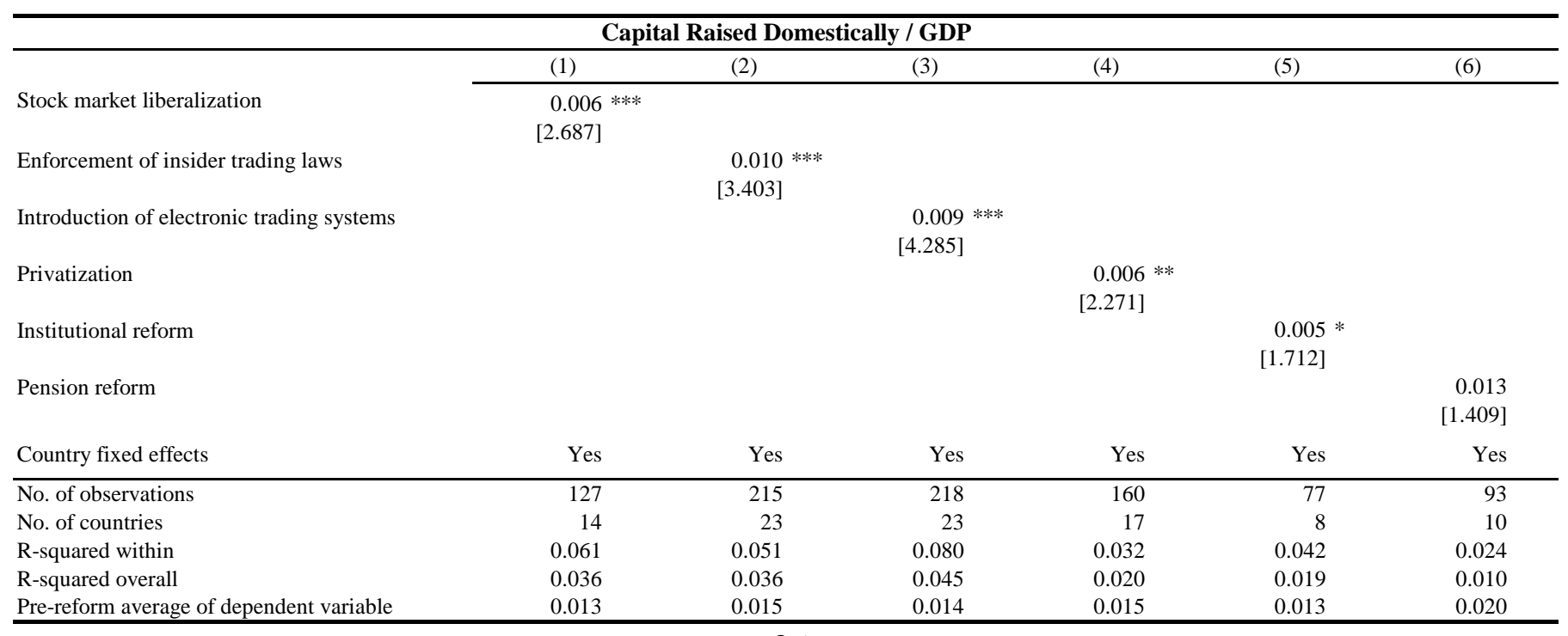


Table 2

\section{Reforms and Stock Market Internationalization}

This table shows least square regressions with robust standard errors estimated using fixed effects models for countries implementing reforms between 1983 and 2000. The regressions consider a ten-year event window around the reform dates (five years before and five years after, including the reform year). The sample includes only countries with at least two observations before the reform date and two afterwards. Absolute values of t-statistics are in brackets. *, **, and *** mean significance at ten, five, and one percent, respectively. See Appendix Table 2 for the definition of the variables.

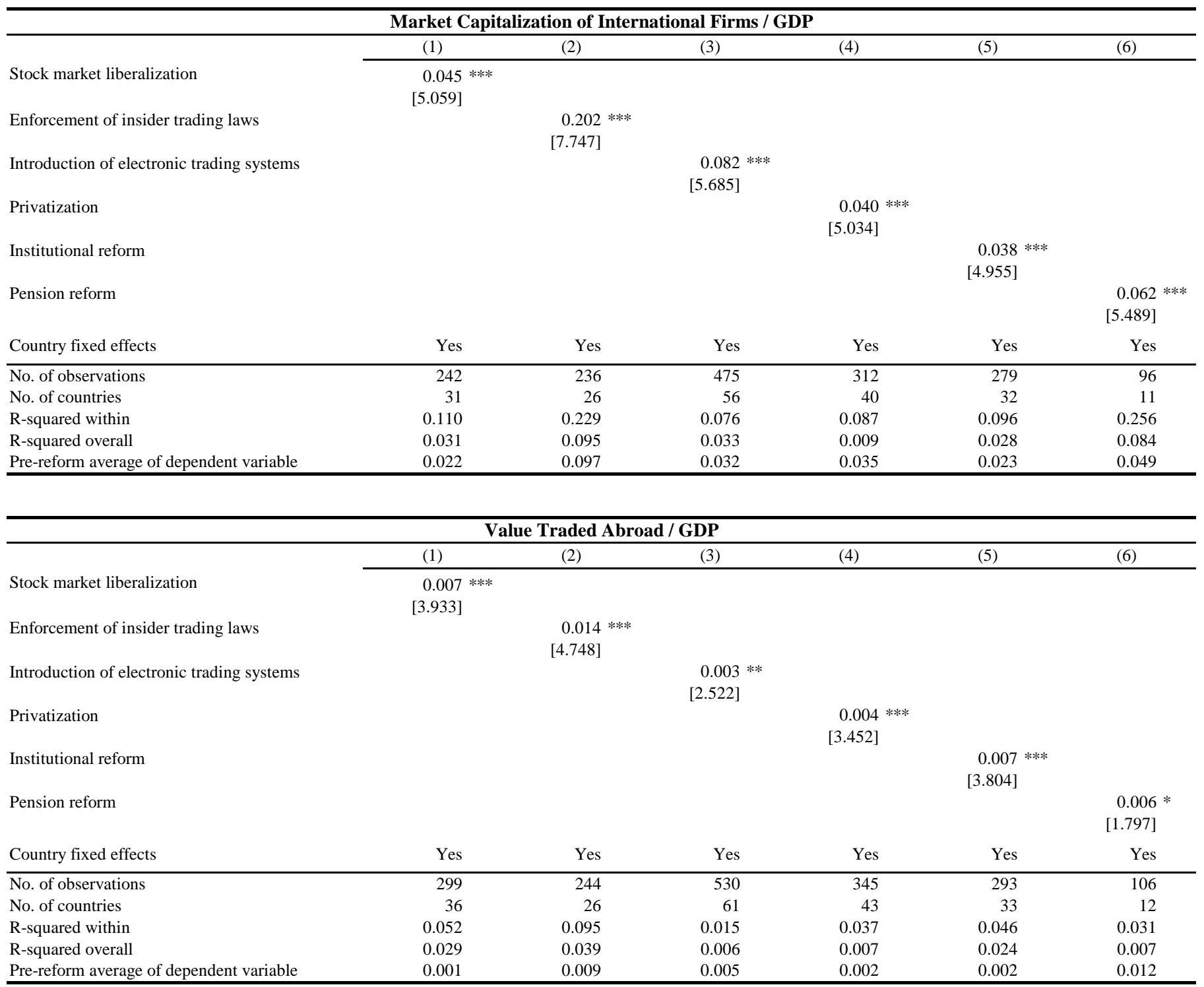

\begin{tabular}{|c|c|c|c|c|c|c|}
\hline \multicolumn{7}{|c|}{ Capital Raised Abroad / GDP } \\
\hline & $(1)$ & (2) & (3) & (4) & $(5)$ & $(6)$ \\
\hline Stock market liberalization & $\begin{array}{l}0.002 \\
{[4.909]}\end{array}$ & & & & & \\
\hline Introduction of electronic trading systems & & & $\begin{array}{l}0.001 \text { *** } \\
{[4.052]}\end{array}$ & & & \\
\hline Institutional reform & & & & & $\begin{array}{l}0.001 \text { *** } \\
{[3.704]}\end{array}$ & \\
\hline Pension reform & & & & & & $\begin{array}{r}0.000 \\
{[0.604]}\end{array}$ \\
\hline Country fixed effects & Yes & Yes & Yes & Yes & Yes & Yes \\
\hline No. of observations & 491 & 307 & 686 & 647 & 409 & 123 \\
\hline
\end{tabular}


Table 3

\section{Reforms and Stock Market Internationalization Relative to Domestic Activity}

This table shows least square regressions with robust standard errors estimated using fixed effects models for countries implementing reforms between 1983 and 2000. The regressions consider a ten-year event window around the reform dates (five years before and five years after, including the reform year). The sample includes only countries with at least two observations before the reform date and two afterwards. Absolute values of t-statistics are in brackets. *,**, and *** mean significance at ten, five, and one percent, respectively. See Appendix Table 2 for the definition of the variables.

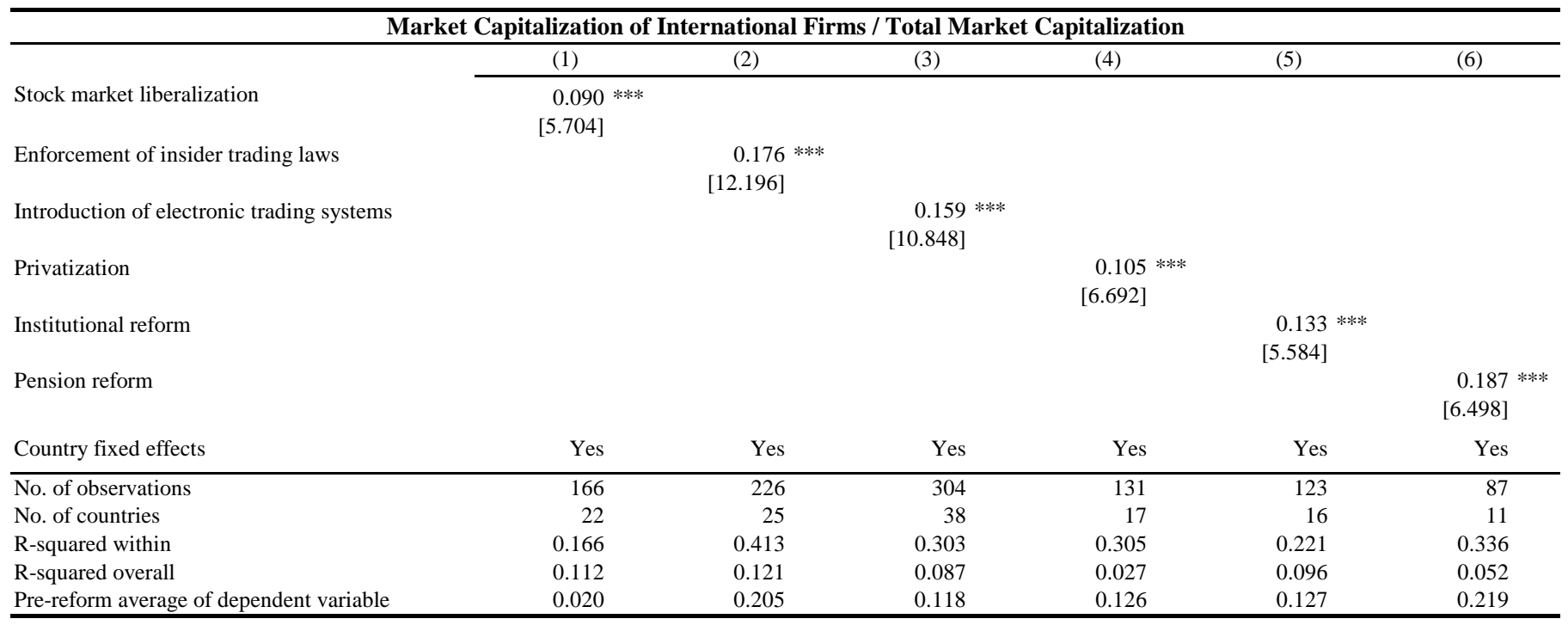

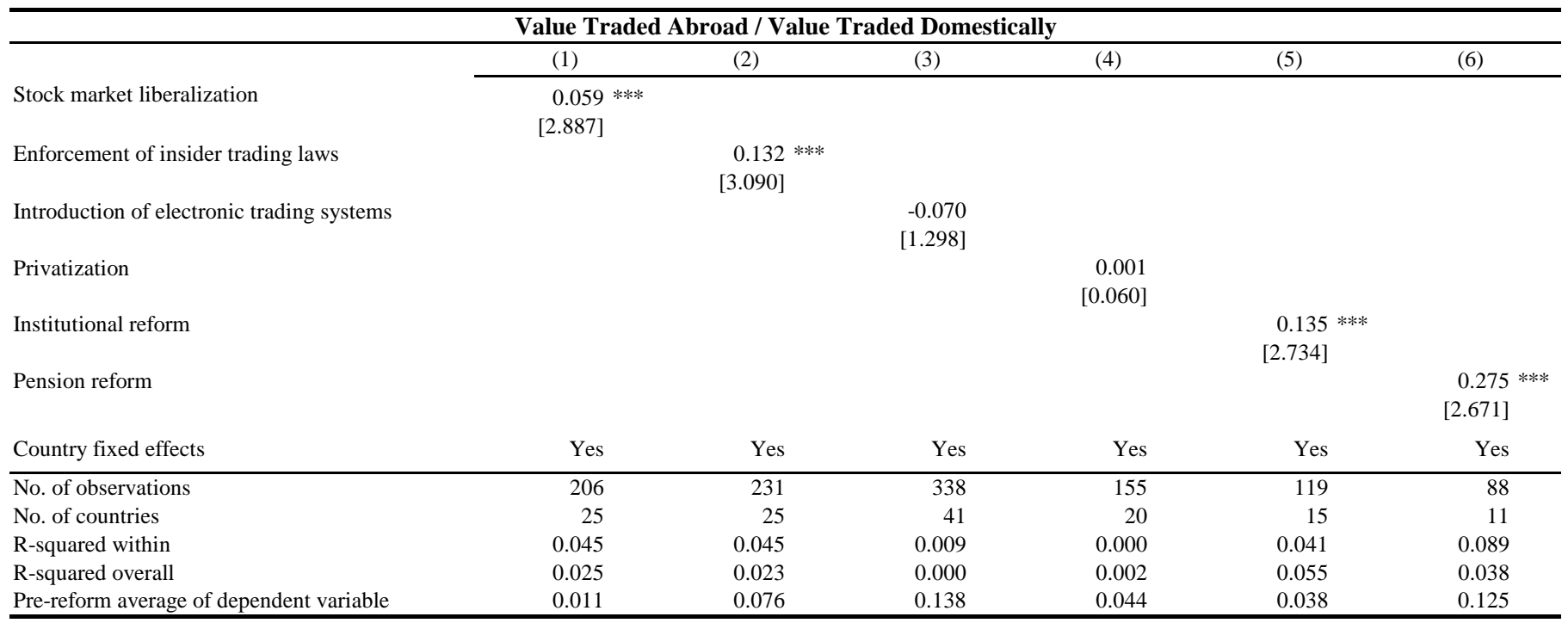

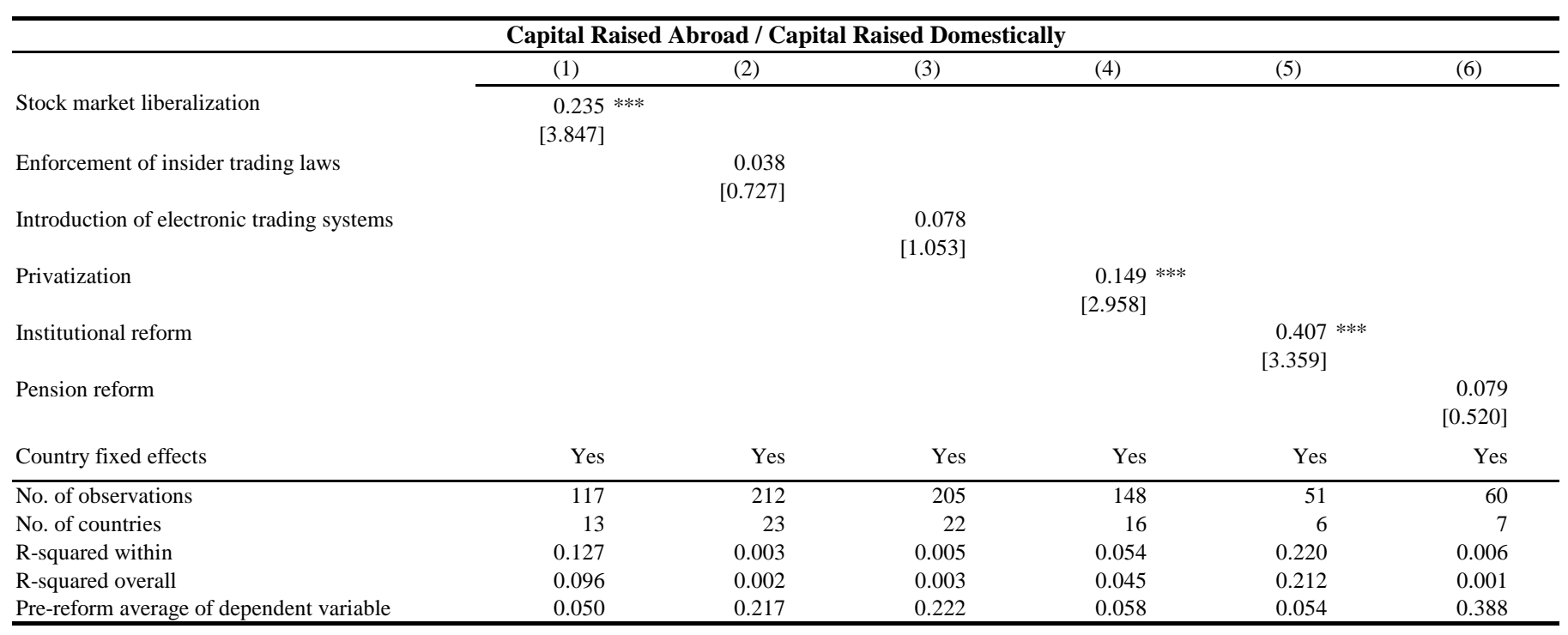




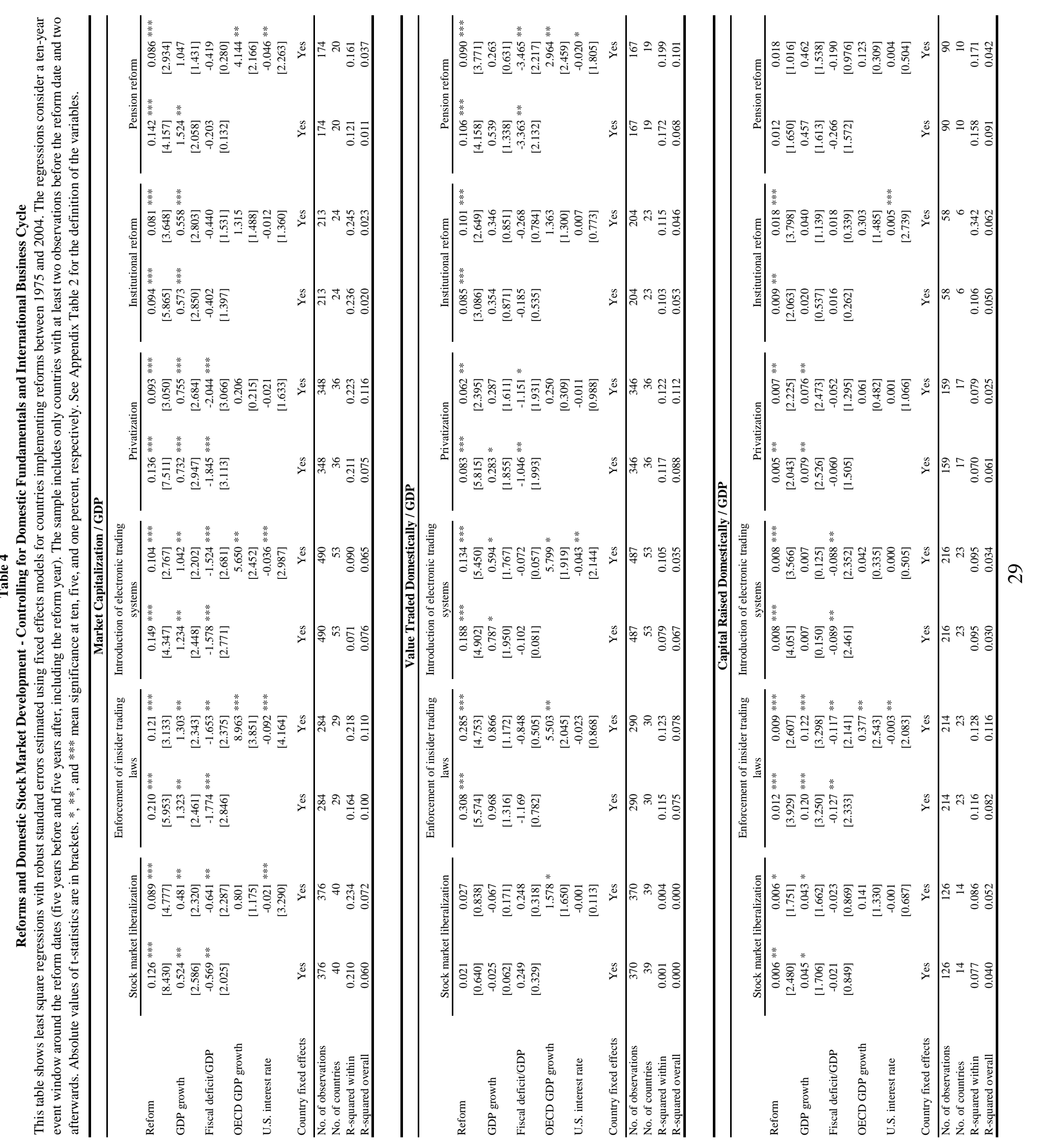




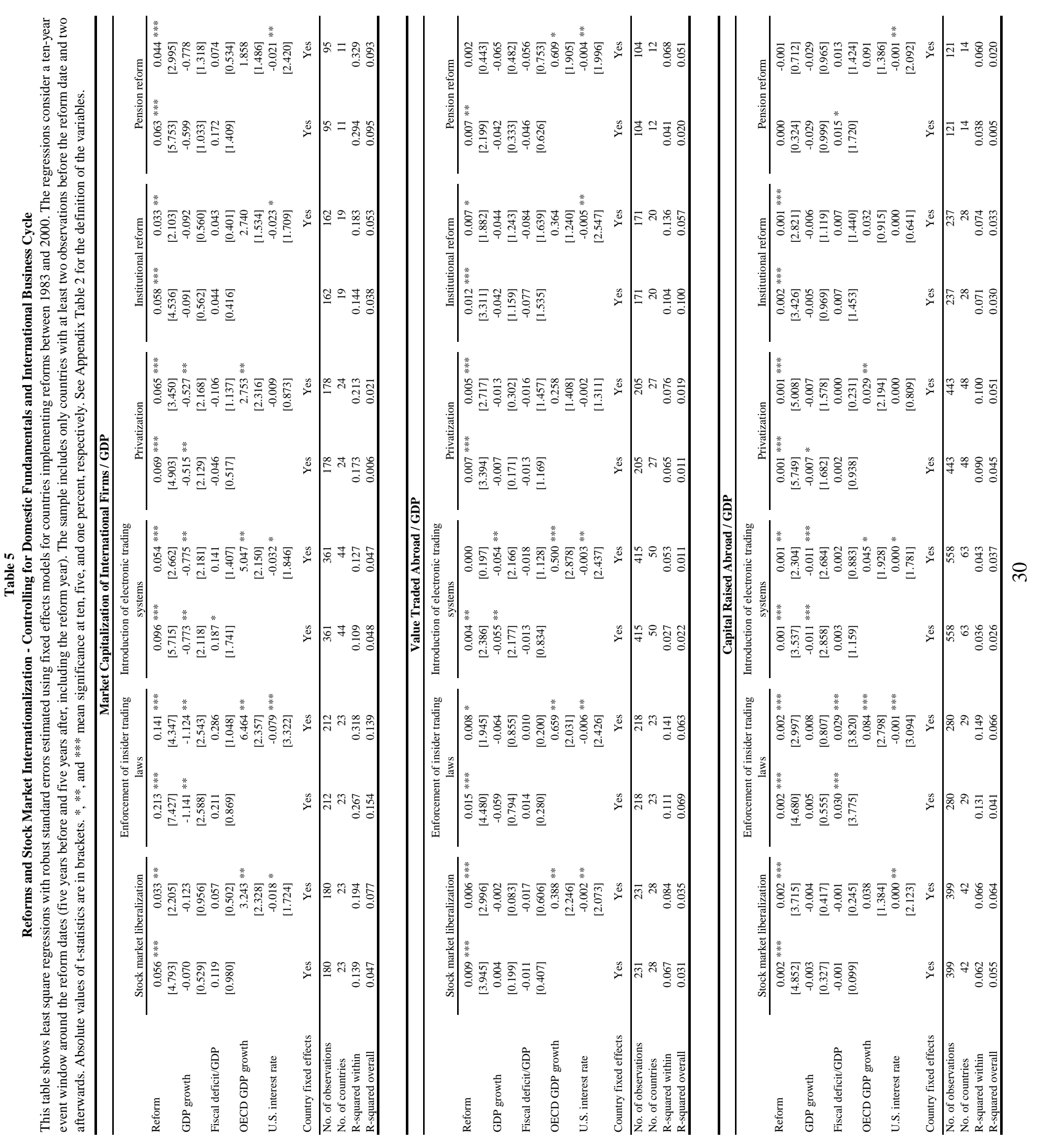




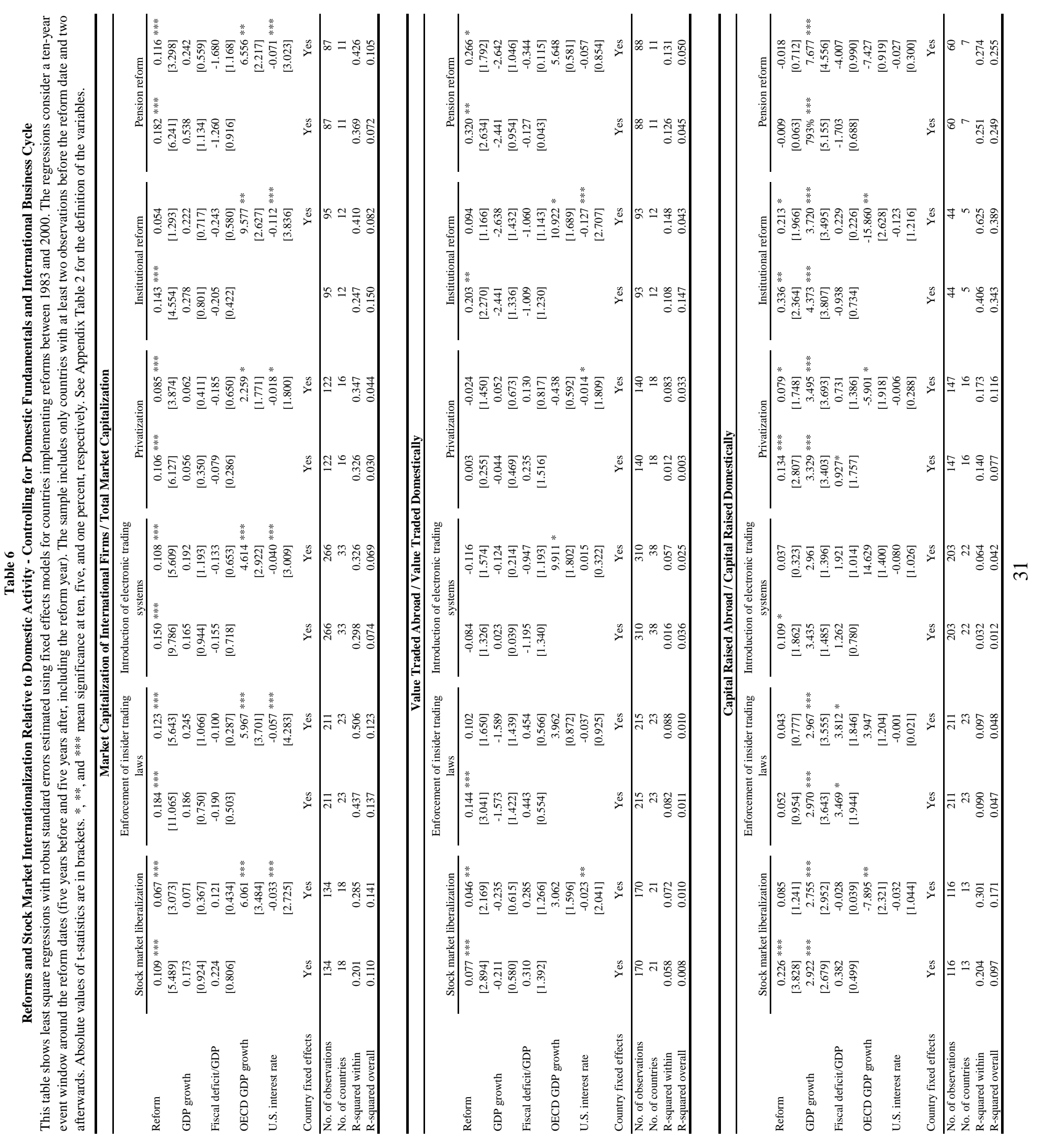




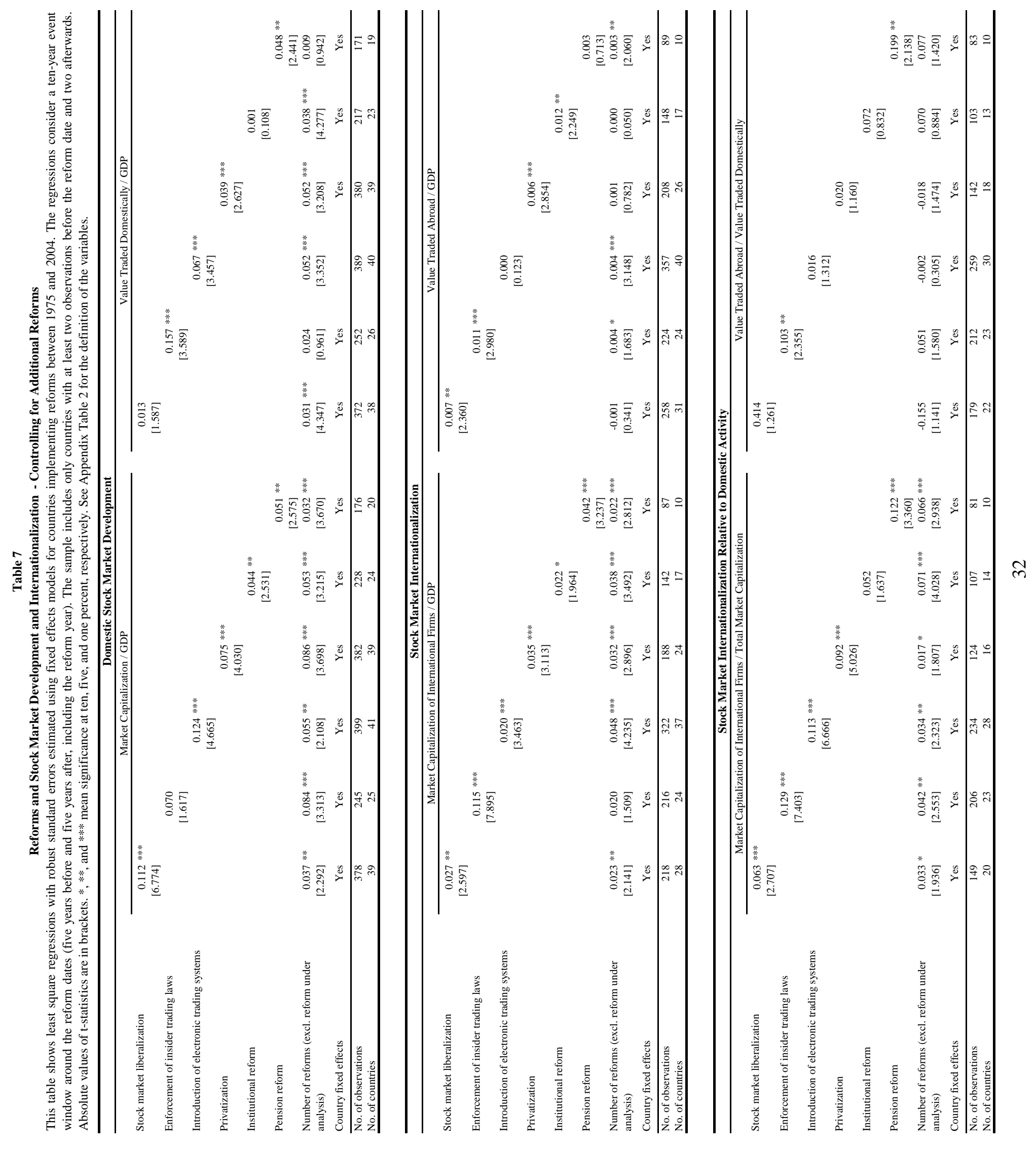


Table 8

Reforms and Domestic Stock Market Development - Controlling for Time Trend

This table shows least square regressions with robust standard errors estimated using fixed effects models for the period 1975-2004. The sample includes only countries with at least six annual observations. Absolute values of t-statistics are in brackets. *, **, and *** mean significance at ten, five, and one percent, respectively. See Appendix Table 2 for the definition of the variables.

\begin{tabular}{|c|c|c|c|c|c|c|}
\hline \multicolumn{7}{|c|}{ Market Capitalization / GDP } \\
\hline & $(1)$ & (2) & (3) & (4) & $(5)$ & (6) \\
\hline Stock market liberalization & $\begin{array}{r}-0.008 \\
{[0.330]}\end{array}$ & & & & & \\
\hline Enforcement of insider trading laws & & $\begin{array}{l}0.171 \text { *** } \\
{[5.343]}\end{array}$ & & & & \\
\hline Introduction of electronic trading systems & & & $\begin{array}{r}0.018 \\
{[0.653]}\end{array}$ & & & \\
\hline Privatization & & & & $\begin{array}{l}0.046 * * \\
{[2.172]}\end{array}$ & & \\
\hline Institutional reform & & & & & $\begin{array}{r}0.021 \\
{[1.206]}\end{array}$ & \\
\hline Pension reform & & & & & & $\begin{array}{l}0.143 \text { *** } \\
{[3.577]}\end{array}$ \\
\hline Time trend & $\begin{array}{l}0.037 \text { *** } \\
{[16.418]}\end{array}$ & $\begin{array}{l}0.029 * * * \\
{[12.470]}\end{array}$ & $\begin{array}{l}0.034 * * * \\
{[15.737]}\end{array}$ & $\begin{array}{l}0.028 * * * \\
{[15.850]}\end{array}$ & $\begin{array}{l}0.034 * * * \\
{[16.748]}\end{array}$ & $\begin{array}{l}0.033 \text { *** } \\
{[17.229]}\end{array}$ \\
\hline Time trend $*$ developing country dummy & $\begin{array}{l}-0.017 \text { **** } \\
{[8.107]}\end{array}$ & $\begin{array}{l}-0.013 \text { *** } \\
{[5.348]}\end{array}$ & $\begin{array}{l}-0.015 \text { *** } \\
{[6.630]}\end{array}$ & $\begin{array}{l}-0.010 \text { *** } \\
{[5.687]}\end{array}$ & $\begin{array}{l}-0.016 \text { *** } \\
{[6.792]}\end{array}$ & $\begin{array}{l}-0.015 \text { *** } \\
{[6.702]}\end{array}$ \\
\hline Country fixed effects & Yes & Yes & Yes & Yes & Yes & Yes \\
\hline $\begin{array}{l}\text { No. of observations } \\
\text { No. of countries }\end{array}$ & $\begin{array}{r}1,731 \\
83 \\
\end{array}$ & $\begin{array}{r}1,834 \\
95 \\
\end{array}$ & $\begin{array}{r}1,887 \\
95 \\
\end{array}$ & $\begin{array}{r}1,527 \\
81 \\
\end{array}$ & $\begin{array}{r}1,926 \\
100 \\
\end{array}$ & $\begin{array}{r}1,916 \\
99 \\
\end{array}$ \\
\hline \multicolumn{7}{|c|}{ Value Traded Domestically / GDP } \\
\hline & (1) & $(2)$ & (3) & (4) & $(5)$ & (6) \\
\hline Stock market liberalization & $\begin{array}{r}-0.020 \\
{[0.558]}\end{array}$ & & & & & \\
\hline Enforcement of insider trading laws & & $\begin{array}{l}0.201 \text { *** } \\
{[5.181]}\end{array}$ & & & & \\
\hline Introduction of electronic trading systems & & & $\begin{array}{l}0.062 * * \\
{[2.365]}\end{array}$ & & & \\
\hline Privatization & & & & $\begin{array}{r}0.026 \\
{[1.428]}\end{array}$ & & \\
\hline Institutional reform & & & & & $\begin{array}{c}0.056 * \\
{[1.864]}\end{array}$ & \\
\hline Pension reform & & & & & & $\begin{array}{r}0.000 \\
{[0.008]}\end{array}$ \\
\hline Time trend & $\begin{array}{l}0.037 \text { **** } \\
{[18.094]}\end{array}$ & $\begin{array}{l}0.028 * * * \\
{[12.667]}\end{array}$ & $\begin{array}{l}0.032 \text { *** } \\
{[14.364]}\end{array}$ & $\begin{array}{l}0.026 * * * \\
{[13.313]}\end{array}$ & $\begin{array}{l}0.034 * * * \\
{[18.676]}\end{array}$ & $\begin{array}{l}0.034 \text { *** } \\
{[18.070]}\end{array}$ \\
\hline Time trend $*$ developing country dummy & $\begin{array}{l}-0.026 \text { *** } \\
{[9.953]}\end{array}$ & $\begin{array}{l}-0.022 \text { *** } \\
{[10.117]}\end{array}$ & $\begin{array}{l}-0.024 * * * \\
{[11.517]}\end{array}$ & $\begin{array}{l}-0.019 \text { *** } \\
{[10.100]}\end{array}$ & $\begin{array}{l}-0.026 * * * \\
{[11.529]}\end{array}$ & $\begin{array}{l}-0.024 \text { *** } \\
{[11.794]}\end{array}$ \\
\hline Country fixed effects & Yes & Yes & Yes & Yes & Yes & Yes \\
\hline No. of observations & 1,681 & 1,814 & 1,830 & 1,496 & 1,862 & 1,864 \\
\hline No. of countries & 79 & 92 & 90 & 78 & 94 & 94 \\
\hline
\end{tabular}

\begin{tabular}{|c|c|c|c|c|c|c|}
\hline \multicolumn{7}{|c|}{ Capital Raised Domestically / GDP } \\
\hline & (1) & (2) & (3) & (4) & $(5)$ & (6) \\
\hline Stock market liberalization & $\begin{array}{r}0.002 \\
{[0.588]}\end{array}$ & & & & & \\
\hline Enforcement of insider trading laws & & $\begin{array}{r}0.005 \\
{[1.601]}\end{array}$ & & & & \\
\hline Introduction of electronic trading systems & & & $\begin{array}{l}0.009 * * * \\
{[4.055]}\end{array}$ & & & \\
\hline Privatization & & & & $\begin{array}{l}0.010 * * * \\
{[3.672]}\end{array}$ & & \\
\hline Institutional reform & & & & & $\begin{array}{r}0.003 \\
{[0.911]}\end{array}$ & \\
\hline Pension reform & & & & & & $\begin{array}{r}0.009 \\
{[1.045]}\end{array}$ \\
\hline Time trend & $\begin{array}{l}0.001 * * * \\
{[5.001]}\end{array}$ & $\begin{array}{l}0.001 \text { *** } \\
{[5.796]}\end{array}$ & $\begin{array}{l}0.001 \text { *** } \\
{[4.513]}\end{array}$ & $\begin{array}{l}0.000 \\
{[2.073]}\end{array}$ & $\begin{array}{l}0.001 \text { *** } \\
{[6.472]}\end{array}$ & $\begin{array}{l}0.001 * * * \\
{[6.739]}\end{array}$ \\
\hline Time trend $*$ developing country dummy & $\begin{array}{l}-0.001 * * * \\
{[3.225]}\end{array}$ & $\begin{array}{l}-0.001 \text { *** } \\
{[3.618]}\end{array}$ & $\begin{array}{l}-0.001 \text { *** } \\
{[2.909]}\end{array}$ & $\begin{array}{c}-0.001 * \\
{[1.845]}\end{array}$ & $\begin{array}{l}-0.001 * * * \\
{[3.654]}\end{array}$ & $\begin{array}{l}-0.001 * * * \\
{[3.565]}\end{array}$ \\
\hline Country fixed effects & Yes & Yes & Yes & Yes & Yes & Yes \\
\hline No. of observations & 725 & 754 & 725 & 516 & 764 & 771 \\
\hline No. of countries & 41 & 42 & 40 & 31 & 42 & 43 \\
\hline
\end{tabular}




\section{Appendix Table 1}

\section{Country Coverage and Reform Dates}

This table shows the list of countries included in the regressions and the dates of the different reforms analyzed by country. Countries with missing values are those with no data to determine whether they implemented the reform or not. "Before sample" means that the country implemented the reform before the start of our sample period (1975). * means that the reform was not included in any of the regressions due to lack of adequate data on the dependent variables for the required period (at least two annual observations before and after the reform date). The list of countries includes countries that did not implement any reform that are included in the regressions in Table 8. See Appendix Table 2 for a definition of the variables and the data sources.

\begin{tabular}{|c|c|c|c|c|c|c|}
\hline & $\begin{array}{l}\text { Stock market } \\
\text { liberalization }\end{array}$ & $\begin{array}{c}\text { Enforcement of } \\
\text { insider trading } \\
\text { laws }\end{array}$ & $\begin{array}{c}\text { Introduction of } \\
\text { electronic } \\
\text { trading systems }\end{array}$ & Privatization & $\begin{array}{c}\text { Institutional } \\
\text { reform }\end{array}$ & Pension reform \\
\hline Albania & . & . & No reform & No reform & 1993 & No reform \\
\hline Argentina & 1989 & 1995 & No reform & 1990 & 1991 & 1994 \\
\hline Armenia & . & No reform & 1996 & 1996 & No reform & No reform \\
\hline Australia & Before sample & 1996 & 1987 & 1991 & No reform & 1993 \\
\hline Austria & Before sample & No reform & 1996 & 1988 & No reform & No reform \\
\hline Azerbaijan & . & . & 1997 & 1997 & No reform & No reform \\
\hline Bahrain & . & No reform & 1999 & No reform & No reform & No reform \\
\hline Bangladesh & 1991 & 1998 & 1998 & No reform & 1987 & No reform \\
\hline Barbados & No reform & No reform & 2000 & No reform & No reform & No reform \\
\hline Belgium & Before sample & 1994 & 1996 & 1990 & No reform & No reform \\
\hline Benin & No reform & . & . & 1988 & 1992 & No reform \\
\hline Bolivia & . & No reform & No reform & 1992 & 1985 & 1997 \\
\hline Botswana & 1990 & No reform & No reform & . & 1998 & No reform \\
\hline Brazil & 1991 & 1978 & No reform & 1991 & 1999 & No reform \\
\hline Bulgaria & 1992 & No reform & 1997 & 1991 & 1997 & 2002 \\
\hline Cambodia & . & . & . & . & 1999 & No reform \\
\hline Cameroon & No reform & . & . & 1998 & No reform & No reform \\
\hline Canada & Before sample & $1976 *$ & 1977 & . & No reform & No reform \\
\hline Chile & 1992 & 1996 & No reform & 1985 & $1976 *$ & 1981 \\
\hline China & . & No reform & 1990 & 1992 & $1978 *$ & No reform \\
\hline Colombia & 1991 & No reform & 1996 & 1991 & No reform & 1994 \\
\hline Costa Rica & No reform & No reform & 1991 & No reform & 1990 & 2000 \\
\hline Cote d'Ivoire & 1995 & . & 1999 & 1991 & No reform & No reform \\
\hline Croatia & . & No reform & 1999 & 1992 & 2000 & 2002 \\
\hline Cyprus & . & No reform & 1999 & . & No reform & No reform \\
\hline Czech Republic & 1993 & 1993 & 1998 & $1991 *$ & $1991 *$ & No reform \\
\hline Denmark & Before sample & 1996 & 1988 & No reform & No reform & 1993 \\
\hline Djibouti & . & . & . & No reform & 1996 & No reform \\
\hline Dominican Republic & No reform & . & . & No reform & $1996 *$ & $2003 *$ \\
\hline Ecuador & 1994 & No reform & No reform & No reform & 2000 & No reform \\
\hline Egypt & 1992 & No reform & No reform & 1993 & No reform & No reform \\
\hline El Salvador & No reform & No reform & 1994 & No reform & 1994 & 1998 \\
\hline Estonia & 1996 & No reform & 1996 & 1993 & 1995 & 2002 \\
\hline Fiji & No reform & . & No reform & No reform & No reform & No reform \\
\hline Finland & 1990 & 1993 & 1988 & 1988 & No reform & No reform \\
\hline France & Before sample & $1975 *$ & 1986 & 1986 & No reform & No reform \\
\hline Georgia & . & . & $2000 *$ & No reform & 1995 & No reform \\
\hline Germany & Before sample & 1995 & No reform & 1988 & No reform & No reform \\
\hline Ghana & 1993 & No reform & No reform & 1989 & 1985 & No reform \\
\hline Greece & 1987 & 1996 & 1992 & 1997 & No reform & No reform \\
\hline Guatemala & No reform & No reform & No reform & No reform & 1994 & No reform \\
\hline Guinea-Bissau & . & . & . & No reform & 1994 & No reform \\
\hline Guyana & No reform & . & . & No reform & 1991 & No reform \\
\hline Honduras & No reform & No reform & 1993 & 1988 & $2003 *$ & No reform \\
\hline Hong Kong & Before sample & 1994 & 1986 & . & No reform & 2000 \\
\hline Hungary & 2000 & 1995 & 1998 & 1989 & 1995 & 1998 \\
\hline Iceland & 1991 & No reform & 1989 & . & No reform & No reform \\
\hline India & 1992 & 1998 & 1995 & 1991 & No reform & No reform \\
\hline Indonesia & 1989 & 1996 & 1995 & 1991 & 1985 & No reform \\
\hline Iran & No reform & No reform & 1994 & No reform & 1999 & No reform \\
\hline Ireland & 1992 & No reform & 2000 & 2001 & No reform & No reform \\
\hline Israel & 1993 & 1989 & 1997 & . & No reform & No reform \\
\hline Italy & Before sample & 1996 & 1994 & 1985 & No reform & No reform \\
\hline Jamaica & 1991 & No reform & 2000 & 1989 & 1993 & No reform \\
\hline Japan & 1983 & 1990 & 1982 & . & No reform & No reform \\
\hline Jordan & 1995 & No reform & 2000 & 2000 & 1998 & No reform \\
\hline Kazakhstan & . & No reform & 1997 & 1994 & No reform & 1998 \\
\hline Kenya & 1995 & No reform & No reform & 1992 & No reform & No reform \\
\hline Korea & 1992 & 1988 & 1988 & . & 1998 & No reform \\
\hline Kuwait & No reform & No reform & 1995 & . & 1986 & No reform \\
\hline Kyrgyz Republic & . & . & 1999 & No reform & No reform & No reform \\
\hline Lao PDR & . & . & . & 1991 & No reform & No reform \\
\hline
\end{tabular}




\section{Appendix Table 1 (Cont.) \\ Country Coverage and Reform Dates}

This table shows the list of countries included in the regressions and the dates of the different reforms analyzed by country. Countries with missing values are those with no data to determine whether they implemented the reform or not. "Before sample" means that the country implemented the reform before the start of our sample period (1975). * means that the reform was not included in any of the regressions due to lack of adequate data on the dependent variables for the required period (at least two annual observations before and after the reform date). The list of countries includes countries that did not implement any reform that are included in the regressions in Table 8. See Appendix Table 2 for a definition of the variables and the data sources.

\begin{tabular}{|c|c|c|c|c|c|c|}
\hline & $\begin{array}{l}\text { Stock market } \\
\text { liberalization }\end{array}$ & $\begin{array}{c}\text { Enforcement of } \\
\text { insider trading } \\
\text { laws }\end{array}$ & $\begin{array}{l}\text { Introduction of } \\
\text { electronic } \\
\text { trading systems }\end{array}$ & Privatization & $\begin{array}{c}\text { Institutional } \\
\text { reform }\end{array}$ & Pension reform \\
\hline Latvia & 1993 & No reform & 1997 & 1995 & 1999 & 2001 \\
\hline Lebanon & . & No reform & No reform & No reform & No reform & No reform \\
\hline Lithuania & 1993 & No reform & 1993 & 1992 & 2000 & 2001 \\
\hline Luxembourg & . & No reform & 1991 & . & No reform & No reform \\
\hline Macedonia & . & No reform & 2001 & 1994 & 1994 & $2003 *$ \\
\hline Malaysia & 1988 & 1996 & 1992 & 1989 & No reform & No reform \\
\hline Malta & 1992 & No reform & 1996 & No reform & $2004 *$ & No reform \\
\hline Mauritius & 1994 & No reform & 2001 & No reform & 1985 & No reform \\
\hline Mexico & 1989 & No reform & 1996 & 1985 & 1991 & 1997 \\
\hline Moldova & . & No reform & 1998 & No reform & No reform & No reform \\
\hline Mongolia & . & No reform & 1999 & . & No reform & No reform \\
\hline Morocco & 1988 & No reform & 1997 & 1993 & No reform & No reform \\
\hline Mozambique & . & . & 1999 & 1989 & No reform & No reform \\
\hline Namibia & . & No reform & 1998 & . & 1995 & No reform \\
\hline Nepal & No reform & . & No reform & No reform & No reform & No reform \\
\hline Netherlands & Before sample & 1994 & 1994 & 1993 & No reform & 1985 \\
\hline New Zealand & 1987 & No reform & 1991 & 1987 & No reform & No reform \\
\hline Nicaragua & No reform & . & . & 1991 & 1994 & $2000 *$ \\
\hline Nigeria & 1995 & No reform & 1999 & 1989 & 2003 & No reform \\
\hline Norway & 1989 & 1990 & 1988 & . & No reform & No reform \\
\hline Oman & 1999 & 1999 & 1998 & No reform & No reform & No reform \\
\hline Pakistan & 1991 & No reform & 1997 & 1991 & No reform & No reform \\
\hline Panama & . & No reform & 1999 & 1992 & 2000 & No reform \\
\hline Papua New Guinea & . & . & 1999 & No reform & No reform & No reform \\
\hline Paraguay & No reform & No reform & No reform & No reform & $2004 *$ & No reform \\
\hline Peru & 1992 & 1994 & No reform & 1991 & 1993 & 1993 \\
\hline Philippines & 1991 & No reform & 1993 & 1991 & 1994 & No reform \\
\hline Poland & 1991 & 1993 & 1996 & 1990 & 1990 & 1999 \\
\hline Portugal & 1986 & No reform & 1991 & 1989 & No reform & No reform \\
\hline Romania & No reform & No reform & 1995 & 1992 & 2000 & No reform \\
\hline Russia & . & No reform & 1994 & 1991 & 2000 & $2004 *$ \\
\hline Saudi Arabia & 1999 & No reform & 1990 & No reform & No reform & No reform \\
\hline Senegal & No reform & . & . & 1997 & 1994 & No reform \\
\hline Serbia and Montenegro & . & . & . & No reform & No reform & No reform \\
\hline Singapore & Before sample & 1978 & 1989 & . & No reform & No reform \\
\hline Slovak Republic & No reform & No reform & 1994 & 1992 & 2000 & 2003 \\
\hline Slovenia & 2001 & 1998 & 1993 & 1992 & 2000 & No reform \\
\hline South Africa & 1996 & No reform & 1996 & 1997 & 1996 & No reform \\
\hline Spain & 1985 & 1998 & 1989 & 1988 & No reform & No reform \\
\hline Sri Lanka & 1991 & 1996 & 1997 & 1990 & 1990 & No reform \\
\hline Swaziland & No reform & No reform & No reform & . & No reform & No reform \\
\hline Sweden & 1980 & 1990 & 1989 & 1992 & No reform & 2001 \\
\hline Switzerland & Before sample & 1995 & 1996 & . & No reform & 1985 \\
\hline Syrian Arab Republic & No reform & . & . & . & $1987 *$ & No reform \\
\hline Taiwan & 1991 & 1989 & 1985 & . & 1980 & No reform \\
\hline Tanzania & . & No reform & No reform & 1992 & 1997 & No reform \\
\hline Thailand & 1987 & 1993 & 1991 & 1993 & No reform & No reform \\
\hline Togo & No reform & . & . & 1990 & 1985 & No reform \\
\hline Trinidad and Tobago & 1997 & No reform & No reform & No reform & 1993 & No reform \\
\hline Tunisia & 1995 & No reform & 1996 & 1988 & No reform & No reform \\
\hline Turkey & 1989 & 1996 & 1993 & 1988 & 2001 & No reform \\
\hline Uganda & . & . & No reform & 1992 & 1996 & No reform \\
\hline Ukraine & . & No reform & 1996 & 1992 & 2000 & No reform \\
\hline United Arab Emirates & . & . & 2000 & No reform & 1988 & No reform \\
\hline United Kingdom & Before sample & 1981 & No reform & 1981 & No reform & 1988 \\
\hline United States & Before sample & Before sample & No reform & . & No reform & No reform \\
\hline Uruguay & No reform & No reform & 1994 & No reform & No reform & 1995 \\
\hline Uzbekistan & . & No reform & 1996 & No reform & No reform & No reform \\
\hline Venezuela & 1990 & No reform & 1992 & 1991 & No reform & No reform \\
\hline West Bank and Gaza & . & . & . & . & No reform & No reform \\
\hline Zambia & No reform & No reform & No reform & 1993 & 1997 & No reform \\
\hline Zimbabwe & 1993 & No reform & No reform & 1994 & No reform & No reform \\
\hline
\end{tabular}



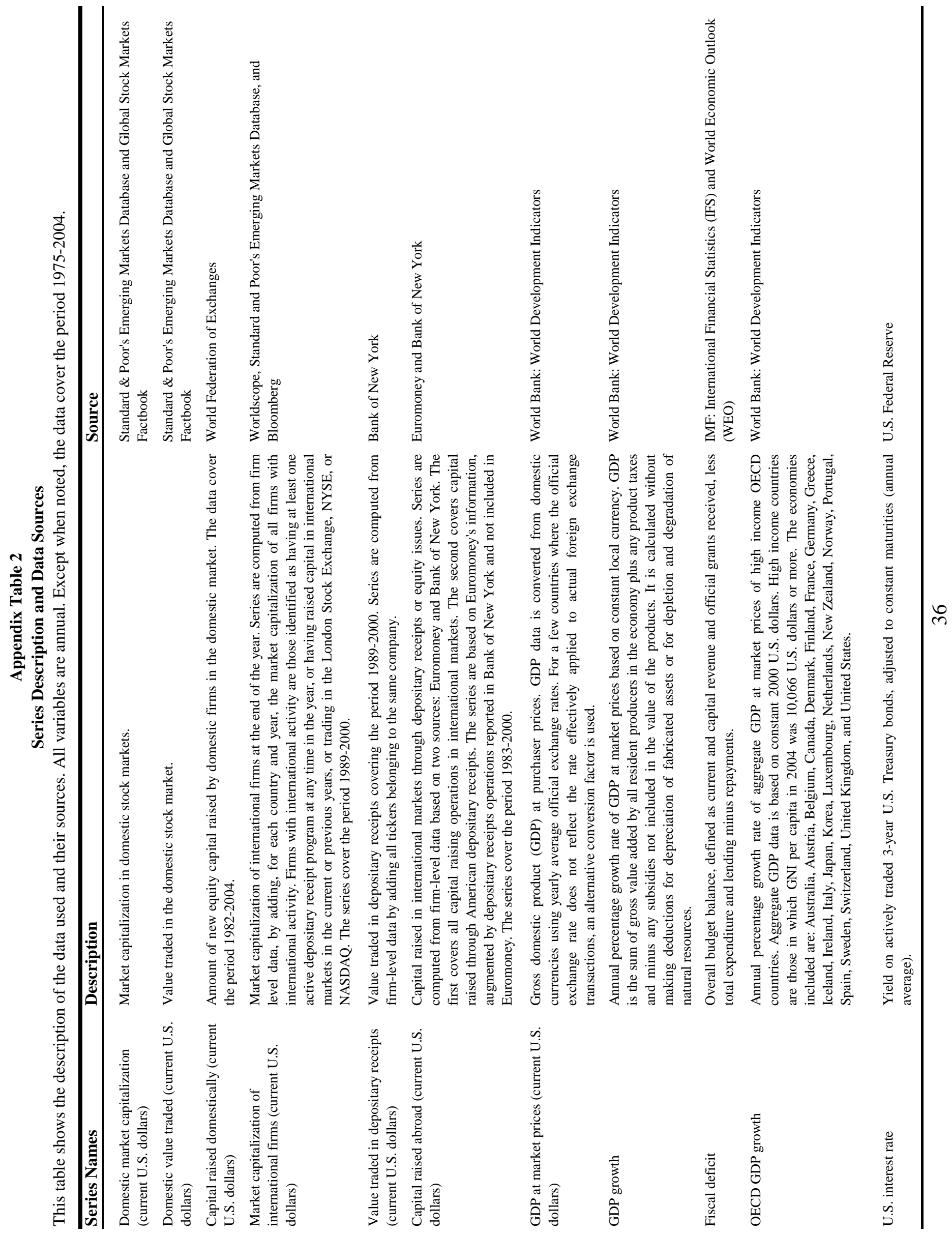

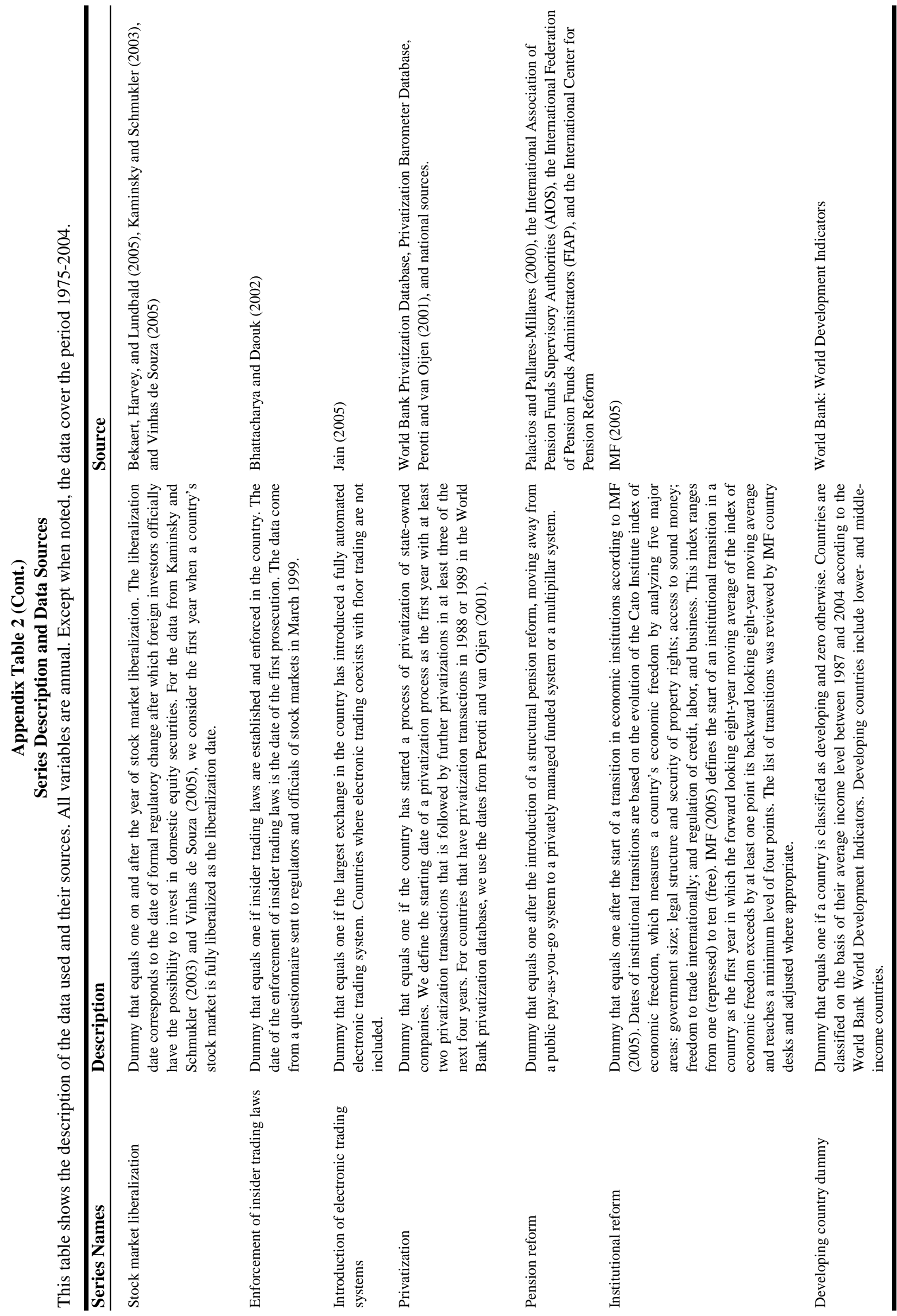